\title{
Comparison of Surface Flow Features from Lidar-Derived Digital Elevation Models with Historical Elevation and Hydrography Data for Minnehaha County, South Dakota
}

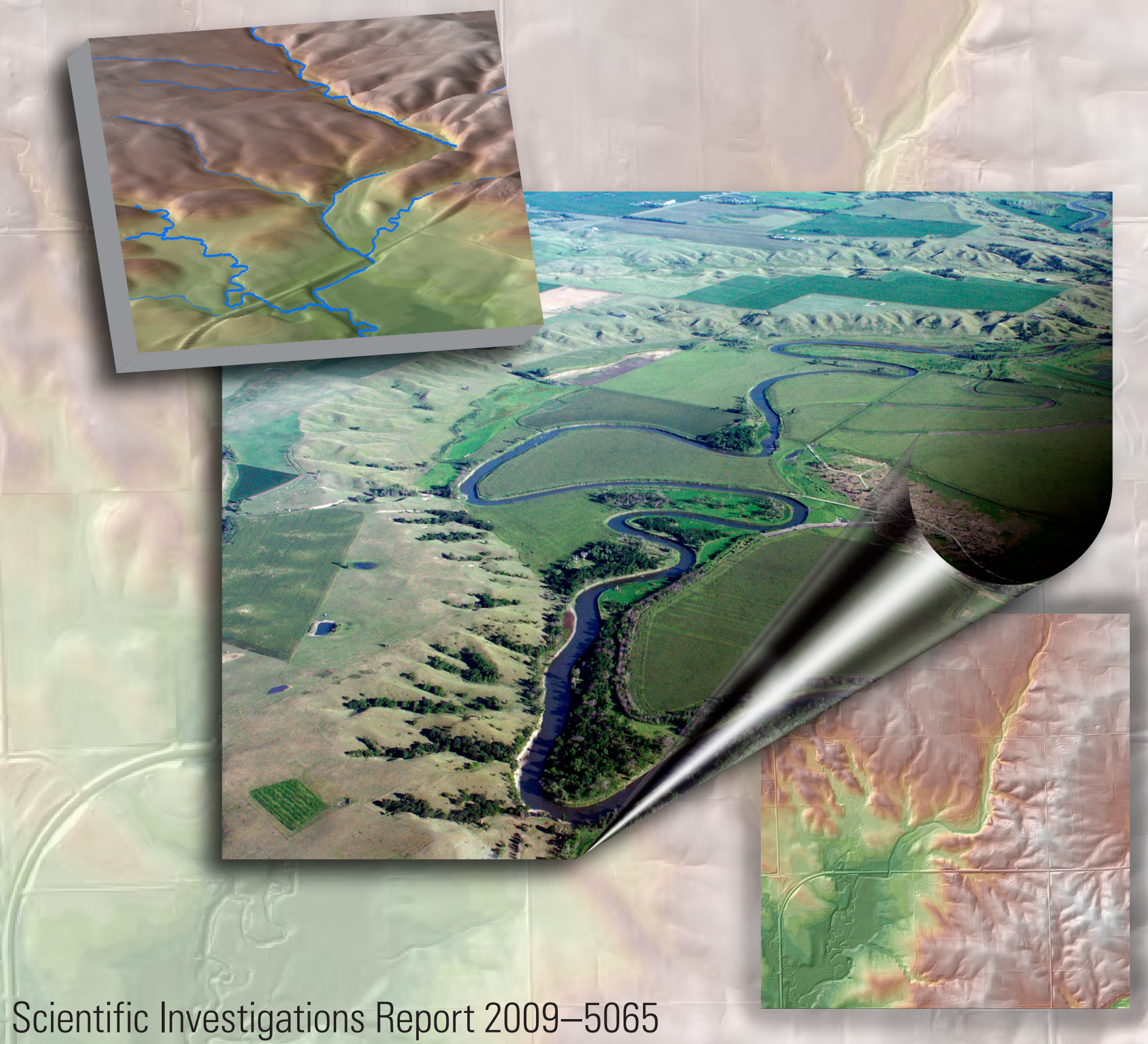

U.S. Department of the Interior

U.S. Geological Survey 
Front cover. Upper left: Clip of lidar-derived surface flow features draped over a three-dimensional lidar-derived digital elevation model (DEM) of Minnehaha County, South Dakota.

Center: Aerial photograph of South Dakota topography by Darrell Napton, South Dakota State University and Visiting Scientist, U.S. Geological Survey.

Lower right: Lidar-derived DEM of Minnehaha County, South Dakota.

Back cover. Lidar-derived DEM of Minnehaha County, South Dakota. 


\section{Comparison of Surface Flow Features from Lidar-Derived Digital Elevation Models with Historical Elevation and Hydrography Data for Minnehaha County, South Dakota}

By Sandra K. Poppenga, Bruce B. Worstell, Jason M. Stoker, and

Susan K. Greenlee

Scientific Investigations Report 2009-5065 


\title{
U.S. Department of the Interior \\ KEN SALAZAR, Secretary
}

\author{
U.S. Geological Survey \\ Suzette M. Kimball, Acting Director
}

U.S. Geological Survey, Reston, Virginia: 2009

For more information on the USGS - the Federal source for science about the Earth, its natural and living resources, natural hazards, and the environment, visit http://wWw.usgs.gov or call 1-888-ASK-USGS

For an overview of USGS information products, including maps, imagery, and publications, visit $h$ ttp://www.usgs.gov/pubprod

To order this and other USGS information products, visit http://store.usgs.gov

Any use of trade, product, or firm names is for descriptive purposes only and does not imply endorsement by the U.S. Government.

Although this report is in the public domain, permission must be secured from the individual copyright owners to reproduce any copyrighted materials contained within this report.

Suggested citation:

Poppenga, S.K., Worstell, B.B., Stoker, J.M., and Greenlee, S.K., 2009, Comparison of surface flow features from lidarderived digital elevation models with historical elevation and hydrography data for Minnehaha County, South Dakota: U.S. Geological Survey Scientific Investigations Report 2009-5065, 24 p. 


\section{Contents}

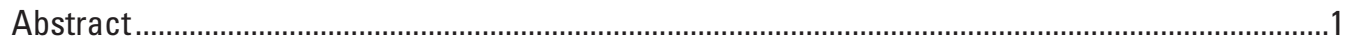

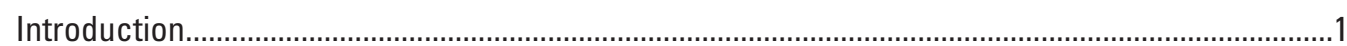

Comparisons of Minnehaha County 1-Meter Lidar-Derived Digital Elevation

Model with Ancillary Datasets ..........................................................................................

Surface Flow Features Derived from Lidar.................................................................................19

Implications for Further Study and Additional Capabilities ...........................................................20

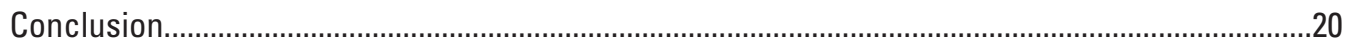

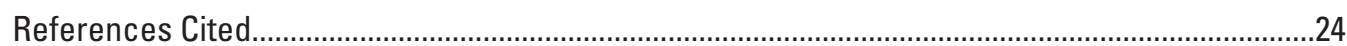

\section{Figures}

1-10. Maps showing:

1. The Elevation, Topographic Science, and Lidar Branch at the U.S. Geological Survey (USGS) Earth Resources Observation and Science (EROS) Center Science Division .....................................................................

2. National Elevation Dataset source information ........................................................

3. Minnehaha County physical geography ..................................................................

4. Minnehaha County lidar-derived elevation ..............................................................

5. 1-meter lidar-derived elevation and 10-meter data incorporated into the National Elevation Dataset .........................................................................6

6. National Hydrography Datatset flowlines overlain on 1-meter lidarderived elevation data in the Sioux Falls Regional Airport area..................................

7. Elevation Derivatives for National Applications overlain on 1-meter lidar-derived elevation data in the Sioux Falls Regional Airport area .......................8

8. National Hydrography Dataset flowlines overlain on 1-meter lidarderived elevation data in rural Minnehaha County showing differences in channel and bridge location

9. Elevation Derivatives for National Applications overlain on 1-meter lidar-derived elevation data in rural Minnehaha County showing differences in channel and bridge location

10. Data from Elevation Derivatives for National Applications, National Hydrography Dataset, and National Bridges Inventory overlain on 1-meter lidar-derived elevation data in rural Minnehaha County showing differences in channel and bridge location.

11. U.S. Geological Survey high-resolution scan of aerial photograph taken in 1958, rural Minnehaha County.....

12. Aerial imagery draped over lidar-derived elevation data in rural Minnehaha County

13. Map showing National Hydrography Dataset "Lake or Pond(s)" overlain on 1-meter lidar-derived elevation data located near the intersection of West 12th Street and Interstate 29, Sioux Falls, South Dakota. 
14. Aerial imagery draped over lidar-derived elevation data in a location that no longer contains National Hydrography Dataset water bodies near the intersection of West 12th Street and Interstate 29, Sioux Falls,

South Dakota

15-16. Maps showing:

15. Contour lines from National Elevation Dataset 1/3-arc-second digital elevation model and from Digital Line Graphs overlain on 1-meter lidar-derived elevation data located near the intersection of West 12th Street and Interstate 29, Sioux Falls, South Dakota ..

16. Contour lines from 1-meter lidar-derived digital elevation model and from Digital Line Graphs overlain on 1-meter lidar-derived elevation data located near the intersection of West 12th Street and Interstate 29, Sioux Falls, South Dakota.

17. Aerial imagery draped over lidar-derived elevation data in a location where National Hydrography Dataset "Lake or Pond(s)" once existed near the intersection of West 12th Street and Interstate 29, Sioux Falls, South Dakota

18-21. Maps showing:

18. Lidar-derived surface flow features overlain on 1-meter lidarderived elevation data in rural Minnehaha County.

19. Lidar-derived surface flow from hydrologically conditioned digital elevation model and downstream trace surface flow derived from National Hydrography Dataset headwater points

20. Surface flow from downstream trace (raindrop) method, derived from National Hydrography Dataset headwater points, and the National Hydrography Dataset flowlines.

21. Difference grid resulting from subtracting values of the original lidarderived digital elevation model from the filled depressionless DEM. 


\section{Conversion Factors and Datums}

\begin{tabular}{lcl}
\hline Multiply & By & To obtain \\
\hline & Length & \\
\hline centimeter $(\mathrm{cm})$ & 0.3937 & inch (in.) \\
meter $(\mathrm{m})$ & 3.281 & foot $(\mathrm{ft})$ \\
meter $(\mathrm{m})$ & 1.094 & yard $(\mathrm{yd})$ \\
kilometer $(\mathrm{km})$ & 0.6214 & mile (mi) \\
kilometer $(\mathrm{km})$ & 0.5400 & mile, nautical (nmi) \\
\hline & Area & \\
\hline square kilometer $\left(\mathrm{km}^{2}\right)$ & 247.1 & acre \\
square kilometer $\left(\mathrm{km}^{2}\right)$ & 0.3861 & square mile $\left(\mathrm{mi}^{2}\right)$ \\
\hline
\end{tabular}

Vertical coordinate information is referenced to the North American Vertical Datum of 1988 (NAVD 88).

Horizontal coordinate information is referenced to the North American Datum of 1983 (NAD 83).

\section{Acronyms}

$\begin{array}{ll}\text { DEM } & \text { digital elevation model } \\ \text { EDNA } & \text { Elevation Derivatives for National Applications } \\ \text { EROS } & \text { Earth Resources Observation and Science (Center) } \\ \text { lidar } & \text { Light detection and ranging } \\ \text { NED } & \text { National Elevation Dataset } \\ \text { NHD } & \text { National Hydrography Dataset } \\ \text { RMSE } & \text { root mean square error } \\ \text { USGS } & \text { U.S. Geological Survey } \\ \text { UTM } & \text { Universal Transverse Mercator }\end{array}$





\title{
Comparison of Surface Flow Features from Lidar-Derived Digital Elevation Models with Historical Elevation and Hydrography Data for Minnehaha County, South Dakota
}

\author{
By Sandra K. Poppenga' ${ }^{1}$ Bruce B. Worstell' ${ }^{2}$ Jason M. Stoker', and Susan K. Greenlee ${ }^{1}$
}

\begin{abstract}
The U.S. Geological Survey (USGS) has taken the lead in the creation of a valuable remote sensing product by incorporating digital elevation models (DEMs) derived from Light Detection and Ranging (lidar) into the National Elevation Dataset (NED), the elevation layer of "The National Map." High-resolution lidar-derived DEMs provide the accuracy needed to systematically quantify and fully integrate surface flow including flow direction, flow accumulation, sinks, slope, and a dense drainage network. In 2008, 1-meter resolution lidar data were acquired in Minnehaha County, South Dakota. The acquisition was a collaborative effort between Minnehaha County, the city of Sioux Falls, and the USGS Earth Resources Observation and Science (EROS) Center. With the newly acquired lidar data, USGS scientists generated high-resolution DEMs and surface flow features. This report compares lidarderived surface flow features in Minnehaha County to 30- and 10 -meter elevation data previously incorporated in the NED and ancillary hydrography datasets. Surface flow features generated from lidar-derived DEMs are consistently integrated with elevation and are important in understanding surfacewater movement to better detect surface-water runoff, flood inundation, and erosion. Many topographic and hydrologic applications will benefit from the increased availability of accurate, high-quality, and high-resolution surface-water data. The remotely sensed data provide topographic information and data integration capabilities needed for meeting current and future human and environmental needs.
\end{abstract}

\section{Introduction}

The U.S. Geological Survey (USGS) is a primary source for seamless elevation data at the global, national, and local scales (Gesch, 2007). Since the early 1990s, the USGS has

\footnotetext{
${ }^{1}$ U.S. Geological Survey.
}

${ }^{2}$ Stinger Ghaffarian Technologies (SGT), Inc., contractor to the U.S. Geological Survey. Work performed under USGS contract O8HQN0005. been developing seamless elevation datasets to incorporate the best publicly available elevation data for research, applications, and distribution (fig. 1). At the global scale, the GTOPO30 elevation model, developed with a 30 -arc-second resolution (about 1 kilometer; Gesch and others, 1999), was the framework for a global HYDRO1k hydrologic application (Verdin and Jenson, 1996). At the national scale, the National Elevation Dataset (NED) was developed in 1999 as the primary source for 30-meter resolution elevation data in the contiguous United States (Gesch and others, 2002). In 2001, nationwide hydrologic derivatives were derived from the NED, integrating surface flow characteristics as the Elevation Derivatives for National Applications (EDNA) database (Franken and others, 2001). At the local scale, the USGS is incorporating lidar-derived digital elevation models (DEMs) into the NED, the elevation layer of "The National Map" (Stoker and others, 2008; http://www.nationalmap.gov). As higher resolution source data (10- and 3-meter resolution or better) are incorporated into the NED, the national elevation model is evolving from a static 30-meter elevation model to a multiresolution model consisting of the best publicly available elevation data (fig. 2). Development of hydrologic derivatives needs to progress at the same pace, thereby providing the best publicly available surface flow features for current and future applications of surface-water data.

The USGS has identified water availability as a high priority and highlights the need for a Water Census of the United States to meet the need for a comprehensive, scientific accounting of the status and trends in freshwater quantity and quality for human and environmental needs (U.S. Geological Survey, 2007). Over the past decade, the USGS has facilitated development of the highest resolution and best publicly available elevation models (fig. 1). To continue that course of action, the USGS has recently taken the lead in the creation of a valuable remote sensing product by incorporating lidarderived DEMs into the NED. Because elevation is a key factor in deriving surface flow features, high-resolution lidar-derived DEMs provide the detail needed to systematically quantify and fully integrate surface flow features and supply topographic spatial information and data integration capabilities needed for the Water Census of the United States. 


\section{Elevation, Topographic Science, and Lidar Branch}

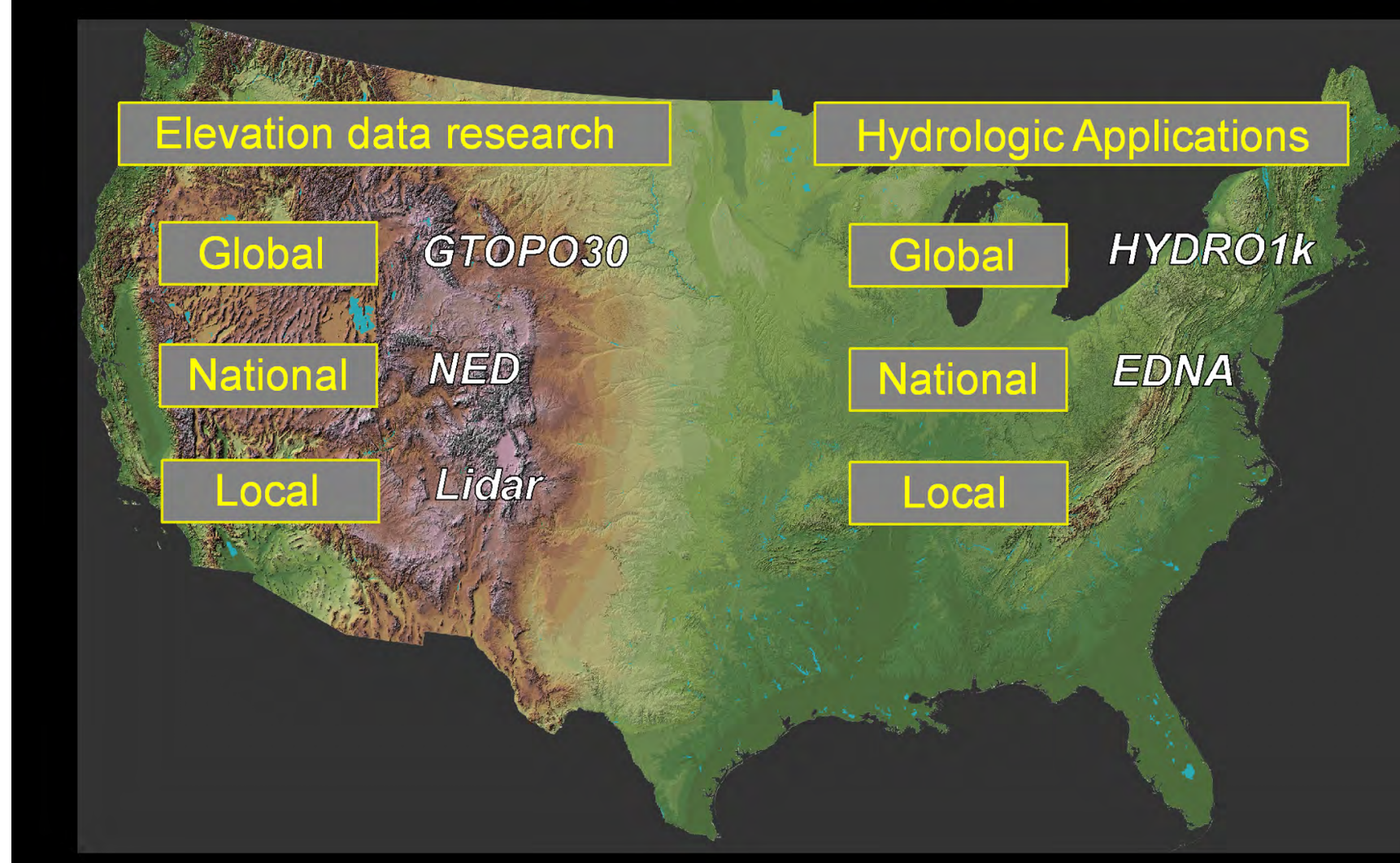

Figure 1. The Elevation, Topographic Science, and Lidar Branch at the U.S. Geological Survey (USGS) Earth Resources Observation and Science (EROS) Center Science Division.

In an effort to support the USGS Water Census science directive, scientists of the Elevation, Topographic Science, and Lidar Branch at the USGS Earth Resources Observation and Science (EROS) Center Science Division are developing surface flow features from high-resolution DEMs derived from remotely sensed bare earth lidar data. In 2008, 1-meter lidar data were acquired in Minnehaha County, South Dakota. The acquisition was a collaborative effort between Minnehaha County, the city of Sioux Falls, and the USGS EROS Center. Using the newly acquired lidar-derived DEMs, scientists generated, analyzed, and compared Minnehaha County surface flow features with historical 30- and 10-meter elevation data previously incorporated in the NED and ancillary hydrography datasets including EDNA and the National Hydrography Dataset (NHD; U.S. Geological Survey, 2008). The comparisons were conducted to incorporate the highest resolution, best publicly available elevation data for hydrologic efficacy.

Lidar is being used as a remote sensing tool in many USGS applications (Queija and others, 2005). From climate change studies of coastal lands vulnerable to sea level rise (Gesch, in press) to debris flow modeling, feature extraction, or hydrologic studies, researchers are frequently using lidar and lidar derivatives to improve the understanding of our planet. 


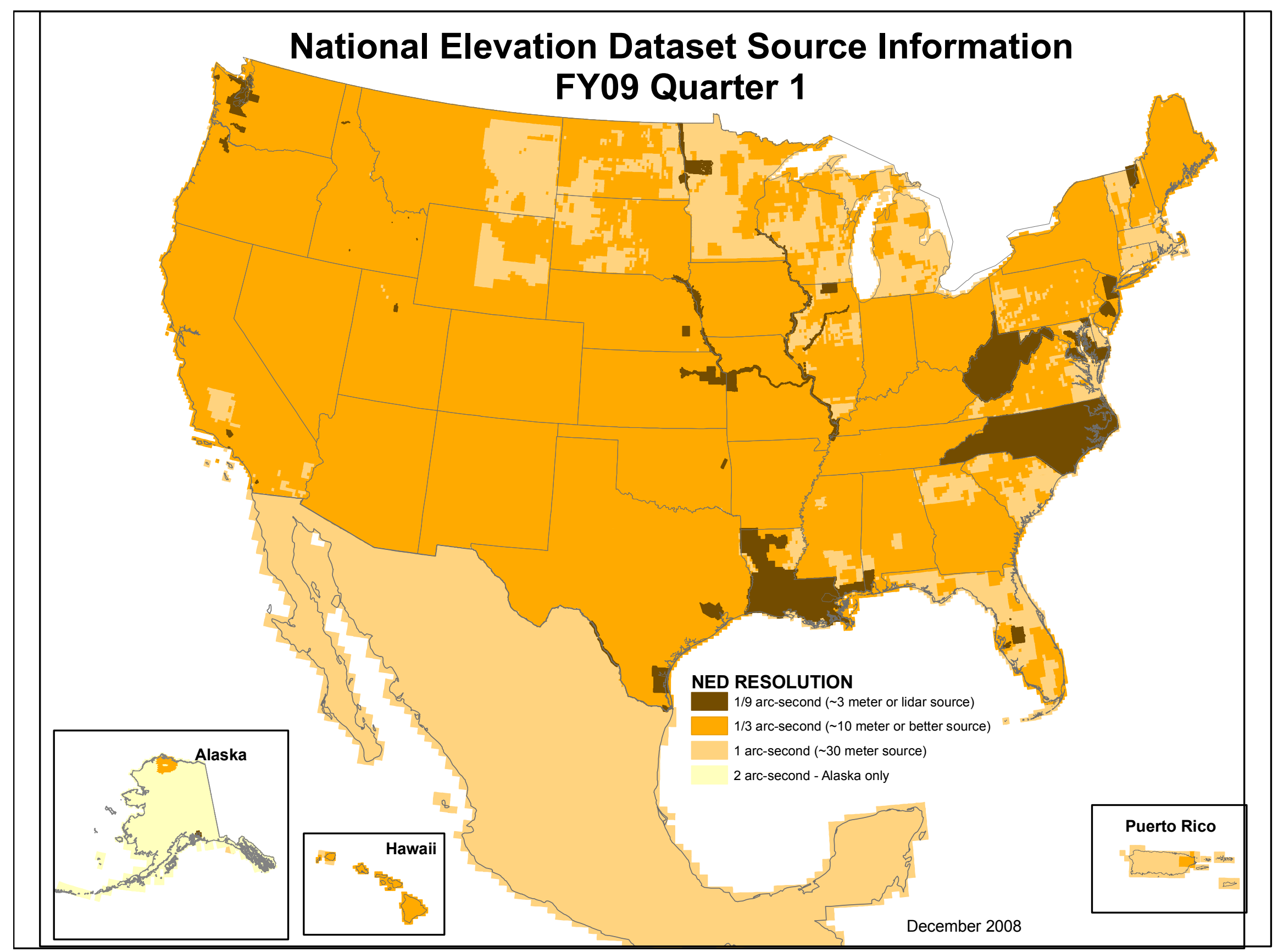

훌
흘
옴

Figure 2. National Elevation Dataset source information. The multiresolution dataset consists of 30-meter, 10-meter, and 3-meter elevation data. 


\section{Comparisons of Minnehaha County 1-Meter Lidar-Derived Digital Elevation Model with Ancillary Datasets}

Minnehaha County, in southeastern South Dakota, has a total area of about 2,108 square kilometers. The county is the most populous in South Dakota with an estimated population of 171,316 (U.S. Census Bureau, 2008). The county seat is Sioux Falls, which is on the southern edge of Minnehaha County and extends into Lincoln County. The physical landscape of Minnehaha County consists of rolling plains on the southern edge of the Coteau des Prairies (Hogan and Fouberg, 2001; fig. 3). Watershed drainage flows generally southward through the county into the Big Sioux River, a tributary of the Missouri and Mississippi Rivers.

Lidar data were collected for Minnehaha County in May 2008 by an airborne platform with a combination of laser range finding, global positioning system, and inertial measurement technologies by Sanborn Map Company Inc. Lidar data accuracy determination uses the National Standard for Spatial Data Accuracy at 18.5 centimeter root mean square error (RMSE) on open bare terrain and 37.0 centimeter RMSE in obscured "vegetative" areas.
The Minnehaha County bare earth lidar data were used to produce 1-meter DEMs with a Universal Transverse Mercator (UTM) Zone 14 projection and an North American Datum of 1983 (NAD83) horizontal datum (fig. 4). At that resolution, the DEM is a detailed representation of the earth's topography and drainage networks. Artificial structures (Sioux Falls Regional Airport, north of Sioux Falls), transportation networks, (Interstates 29 and 90) and drainage networks (Big Sioux River) can be identified in figure 4. In the smaller area shown in figure 5, the Big Sioux River, channelized throughout the years, flows to the west of the airport, and a diversion channel drains to the east of the airport. The current lidar (1-meter) elevation data more accurately represent surface flow in low relief areas than the historical 10-meter elevation data (fig. 5), which were previously incorporated into the NED. This temporal elevation comparison emphasizes the need for elevation data currency to provide the best publicly available elevation framework for precise representation of surface flow.

Historically, surface flow features have been either cartographically derived from aerial photography or digitally developed from moderate resolution (30-meter) elevation data. Because different types of source data were used to create each dataset (cartographically or digitally developed),

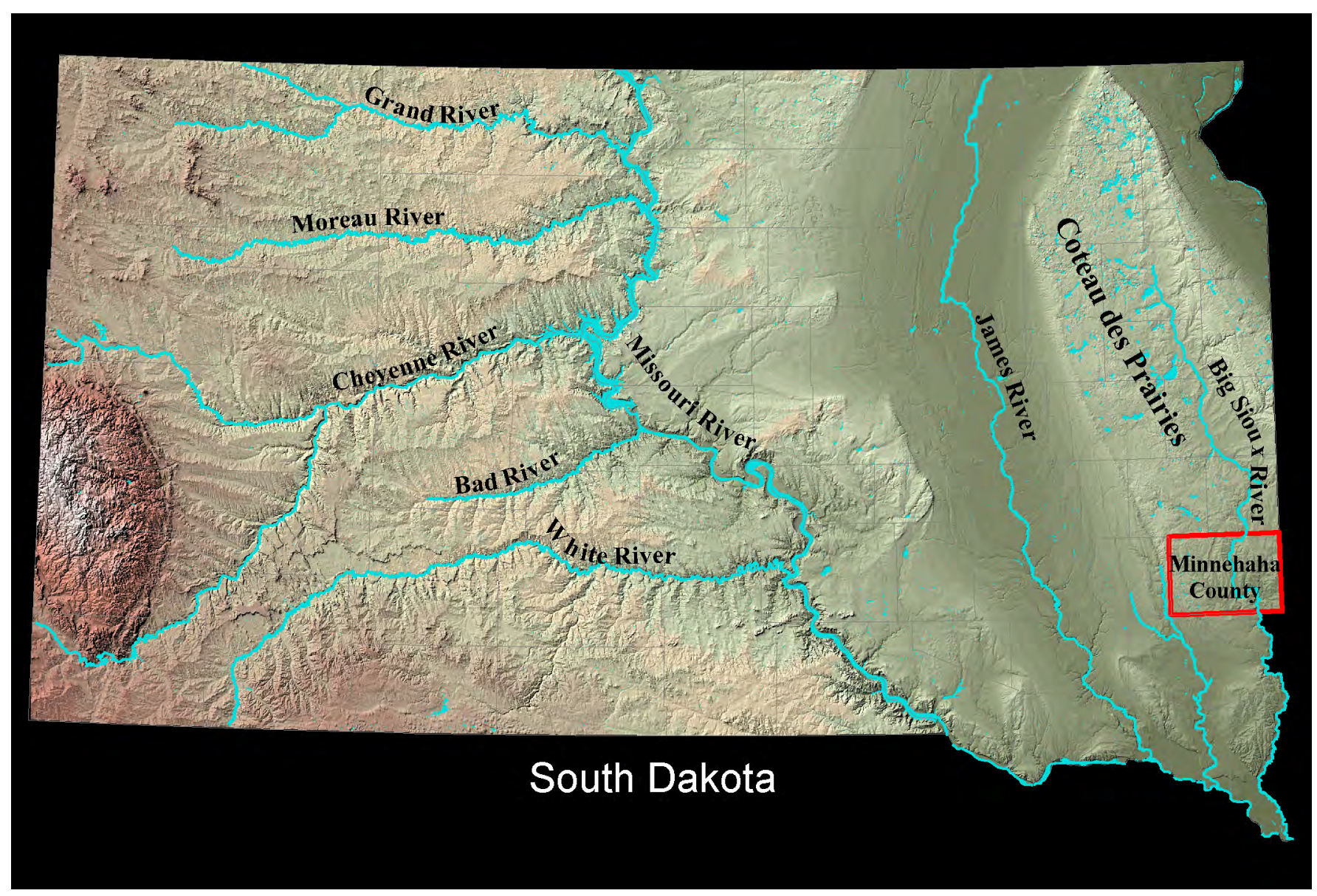

Figure 3. Minnehaha County physical geography. 
integration can be problematic. Thus, comparisons were conducted to determine the efficacy of integrating ancillary hydrography data with 1-meter lidar-derived elevation data for Minnehaha County.

In figure 6 , the lidar-derived shaded relief is overlain with NHD flowlines. At this location, the airport runways are surrounded by the Big Sioux River where the natural channel flows to the west and a diversion channel drains to the east. There is an estimated difference of 609.6 meters (2,000 feet) between the Big Sioux River channel and NHD flowlines. A comparison of the same area with the 30-meter EDNA synthetic streamlines overlain on lidar-derived shaded relief shows substantial deviation of surface flow (fig. 7). Although nationwide EDNA hydrologic derivatives were created in 2001, the surface flow for this geographic area was derived from DEM source data within the NED that, in 2001, had not yet been updated to 10-meter or better resolution. Representation of the flat area to the west of the airport is inaccurate because of old elevation source data used when the 30-meter hydrologic derivatives were created in 2001.

Comparisons conducted in rural areas of Minnehaha County resulted in similar issues. In figure 8, NHD flowlines overlain on lidar-derived shaded relief portray an estimated 152.4-meter (500-foot) difference between NHD flowlines and the current location of the channel. An analysis of the EDNA synthetic streamlines overlain on the lidar-derived shaded relief resulted in the same discrepancy (fig. 9). Such variances exist in other ancillary datasets including the U.S. Department of Transportation Federal Highway Administration National Bridges Inventory (NBI; fig. 10; U.S. Department of Transportation Federal Highway Administration, 2007). Although the present bridge location is accurately represented in the 1-meter lidar-derived DEM, the bridge was in a different location prior to the 1970s. An aerial photograph of the area in 1958 shows flow meandering west of the present bridge location (fig. 11). The stream was channelized and the bridge was moved to its present location in the early 1970s because of the construction of a highway that would provide access to the USGS EROS Center (fig. 12).

Comparing NHD water bodies with the lidar-derived DEM in Minnehaha County revealed that some water bodies no longer exist. In figure 13, NHD "Lake or Pond(s)" are overlain on the lidar-derived shaded relief. This area currently contains parking with railroad access and tank storage where three NHD "Lake or Pond(s)" are represented in the NHD dataset (fig. 14). Contour lines from the $1 / 3$-arc-second (10-meter) NED (fig. 15) and from lidar (fig. 16) go through the NHD "Lake or Pond(s)," which is an indicator that a water body no longer exists. However, contour lines from the older Digital Line Graphs (DLGs) still encircle the "Lake or Pond(s)." The top left NHD "Lake or Pond(s)" in figure 13 also no longer exists: overland surface flow has been routed

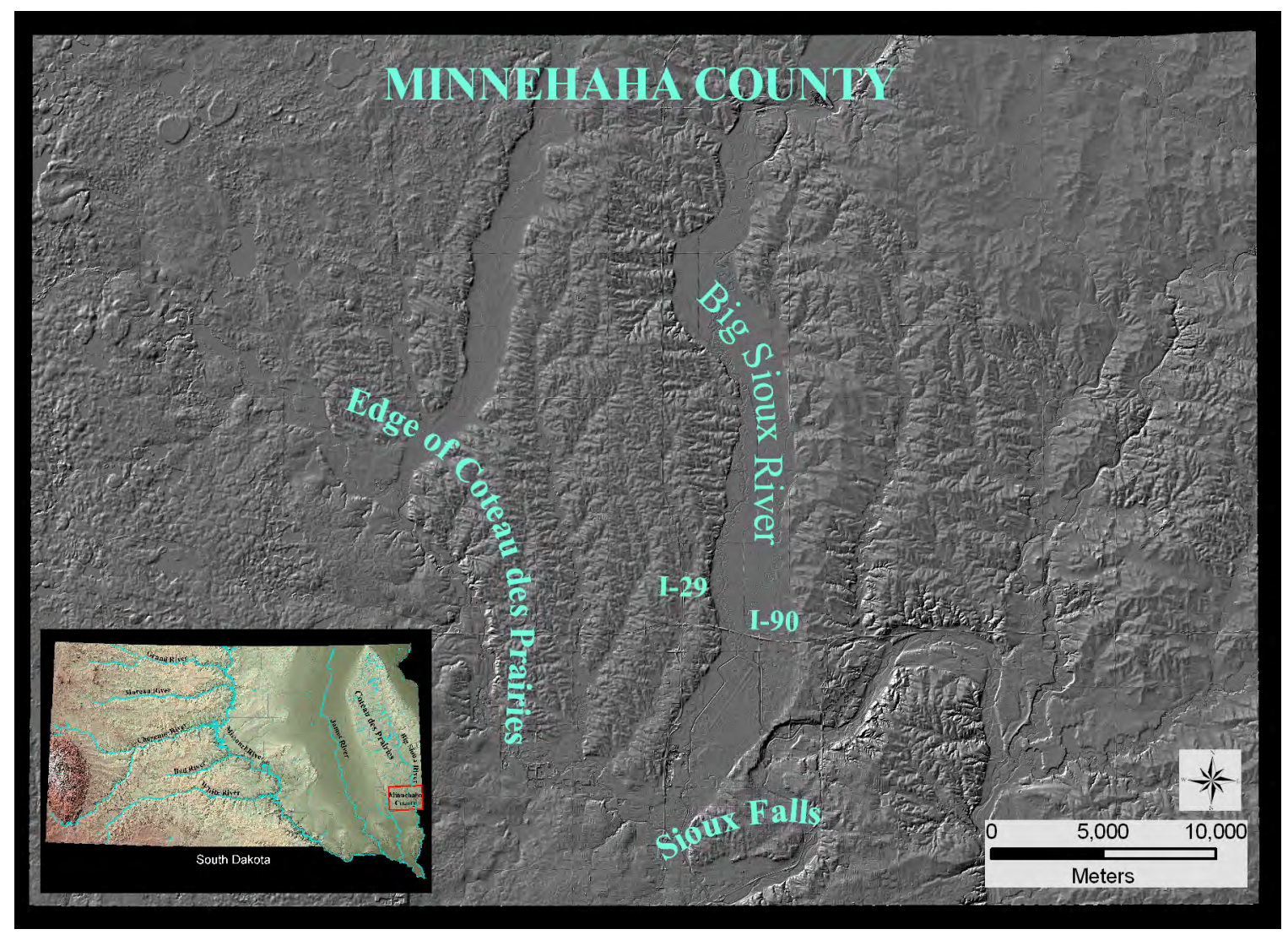

Figure 4. Minnehaha County lidar-derived elevation. 

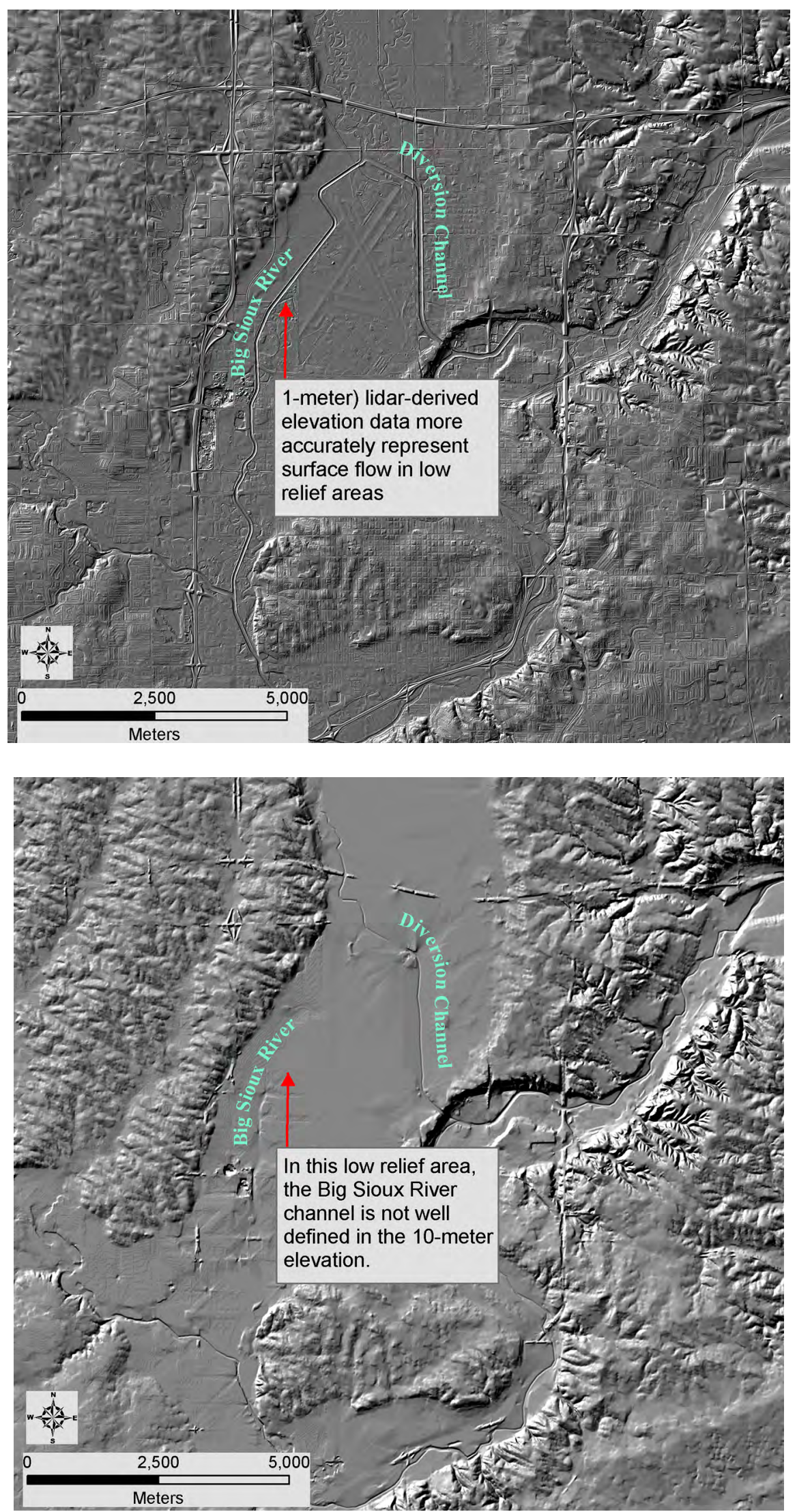

Figure 5. 1-meter lidar-derived elevation (top) and 10-meter data (bottom) incorporated into the National Elevation Dataset. 


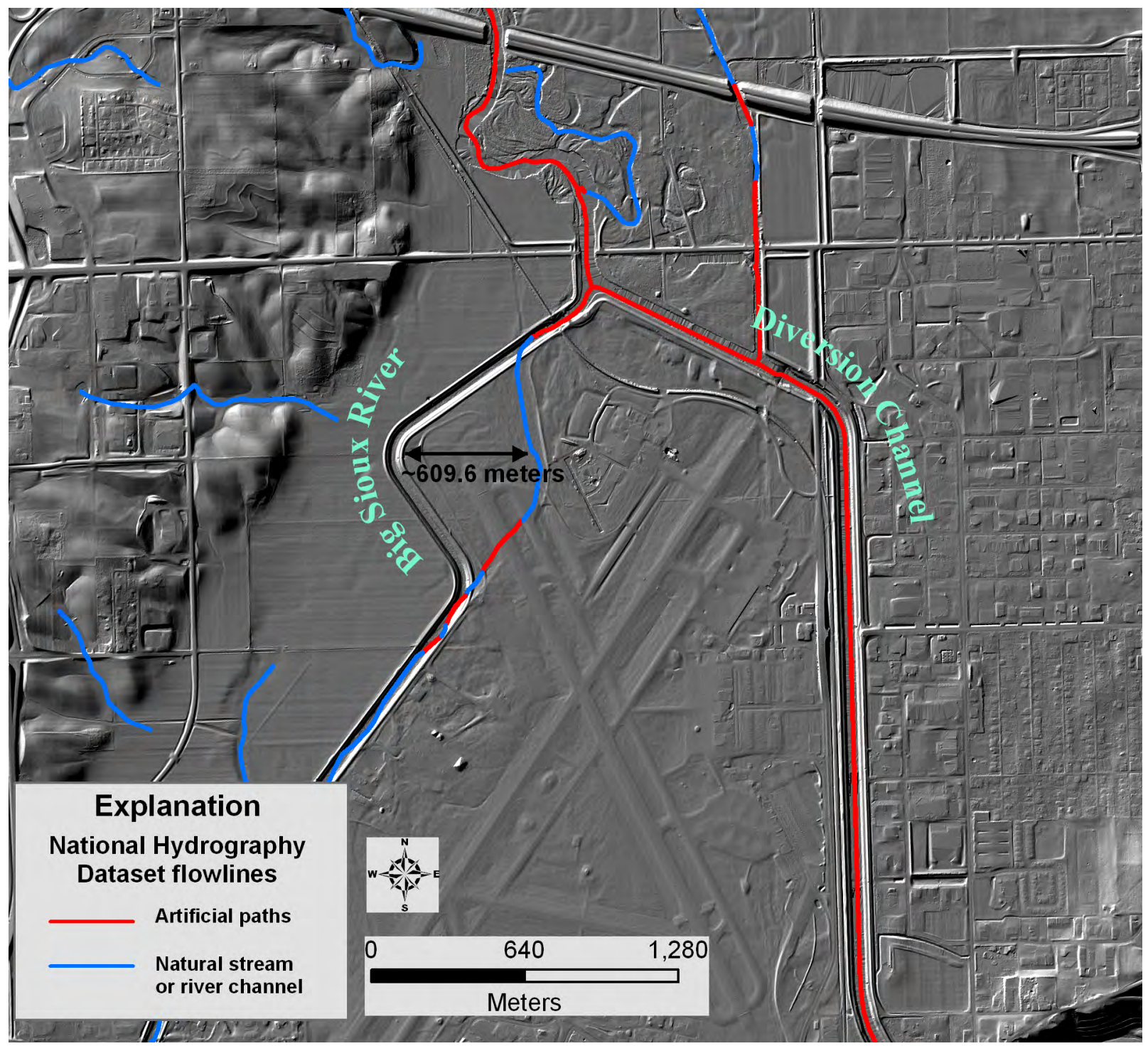

Figure 6. National Hydrography Datatset flowlines overlain on 1-meter lidar-derived elevation data in the Sioux Falls Regional Airport area. 


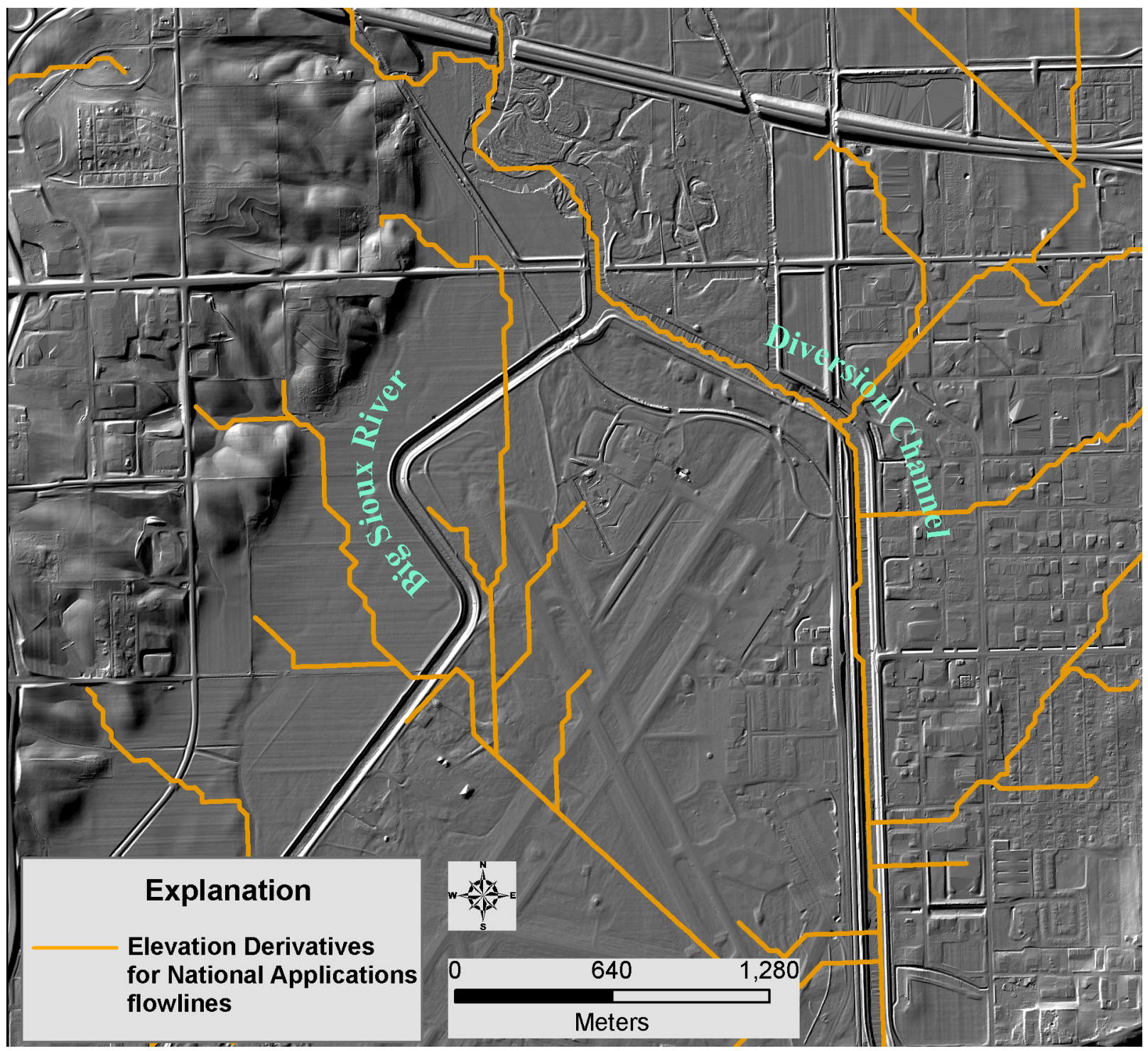

Figure 7. Elevation Derivatives for National Applications overlain on 1-meter lidar-derived elevation data in the Sioux Falls Regional Airport area. 


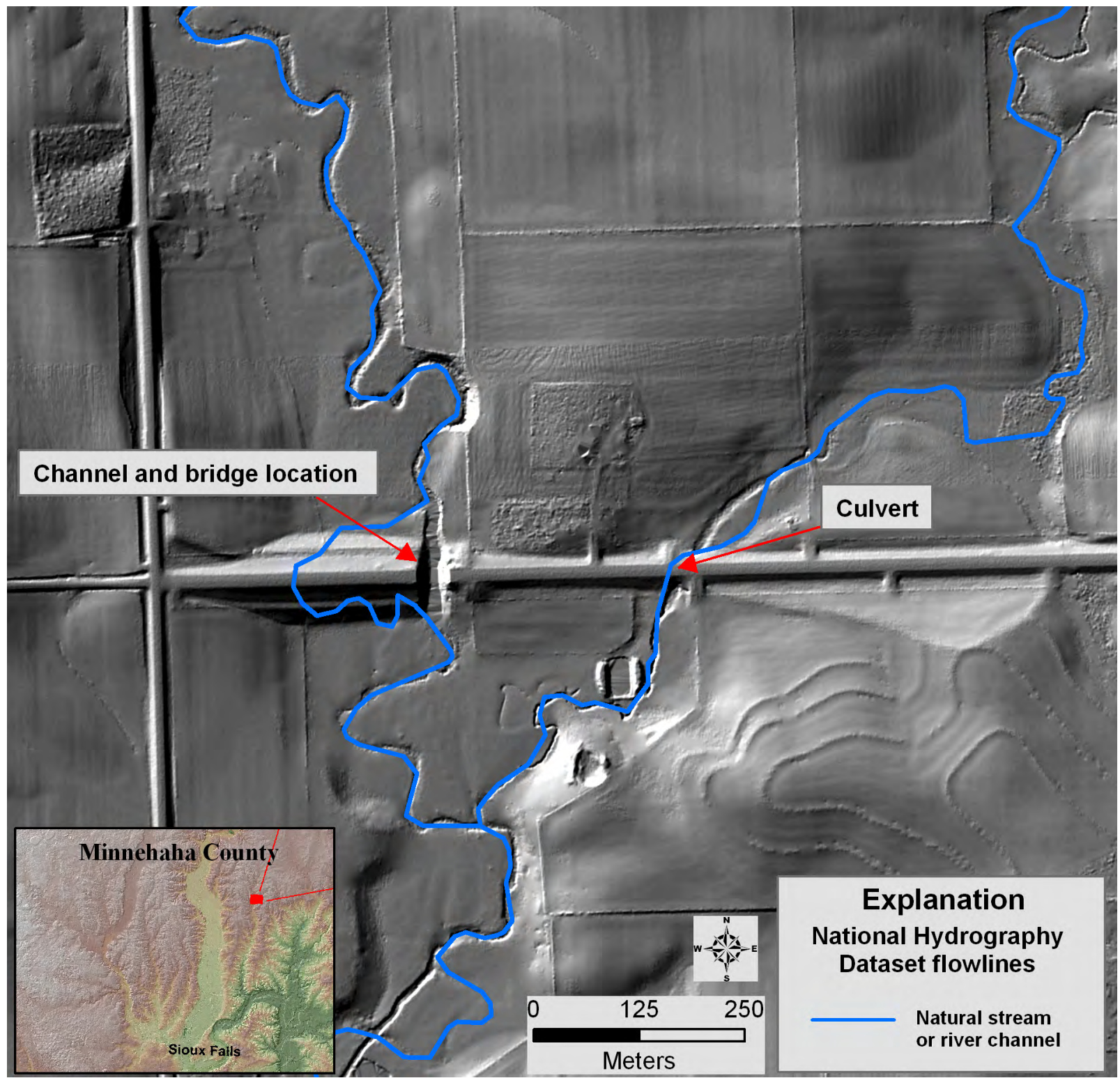

Figure 8. National Hydrography Dataset flowlines overlain on 1-meter lidar-derived elevation data in rural Minnehaha County showing differences in channel and bridge location. 


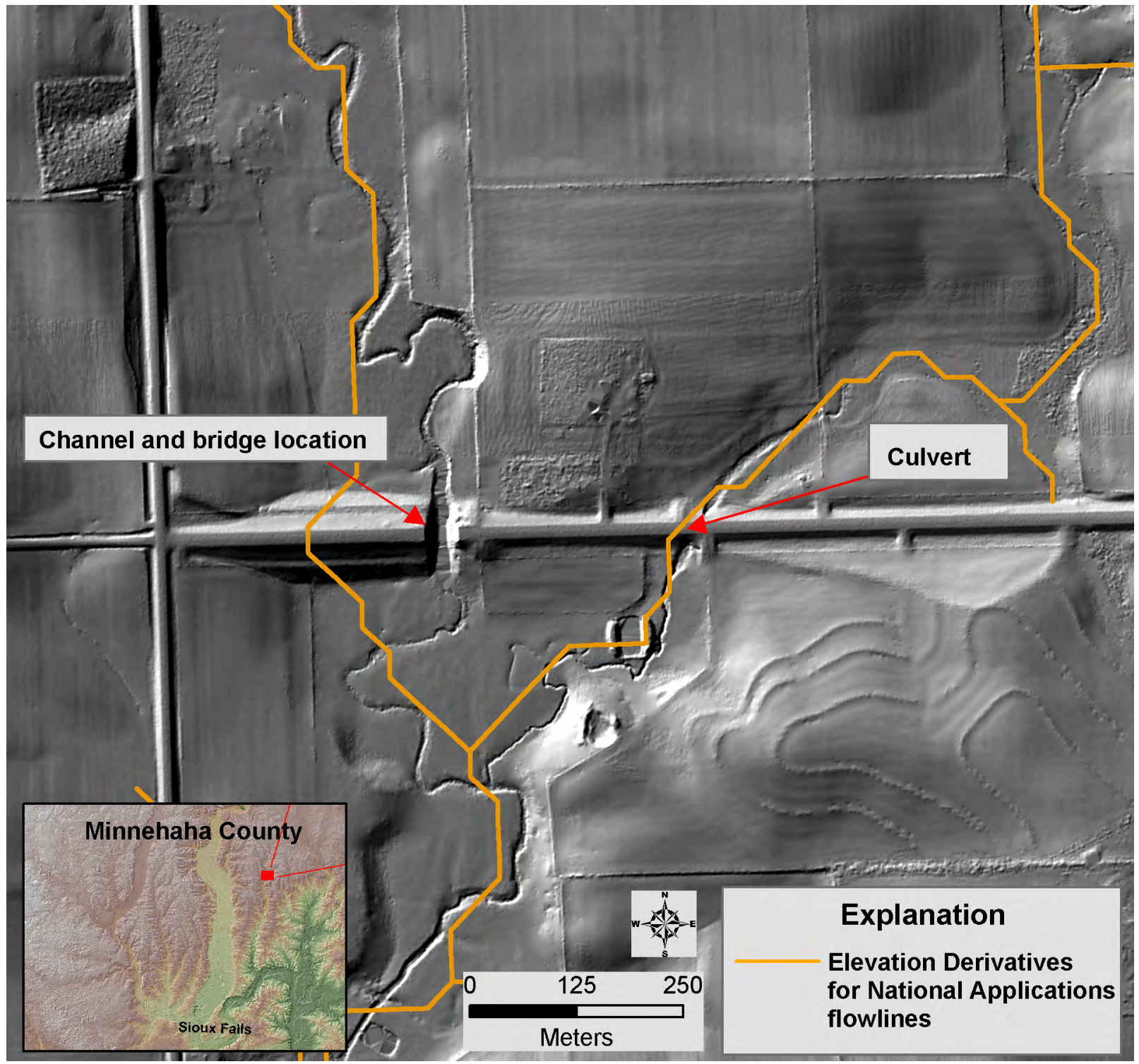

Figure 9. Elevation Derivatives for National Applications overlain on 1-meter lidar-derived elevation data in rural Minnehaha County showing differences in channel and bridge location. 


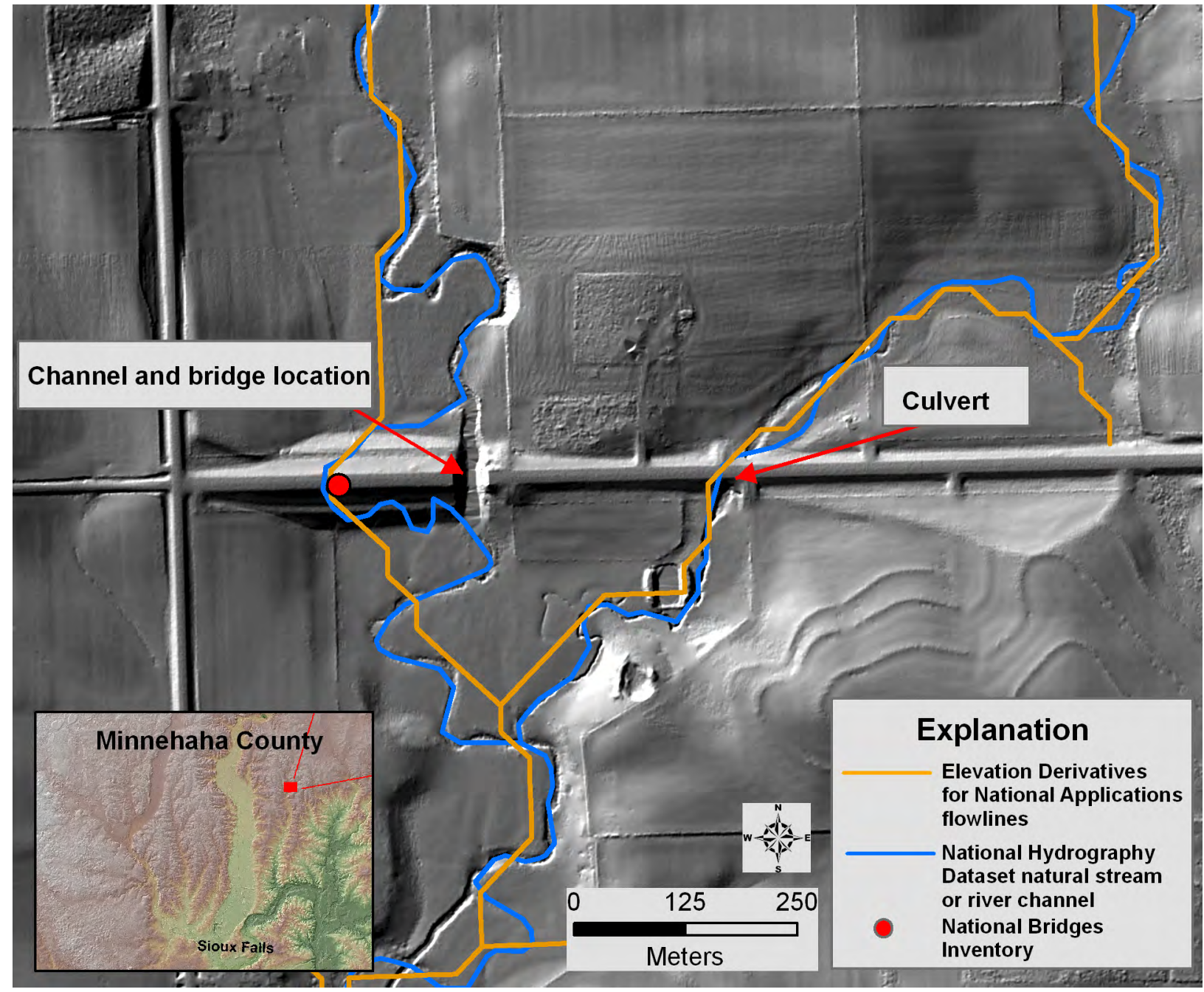

Figure 10. Data from Elevation Derivatives for National Applications, National Hydrography Dataset, and National Bridges Inventory overlain on 1-meter lidar-derived elevation data in rural Minnehaha County showing differences in channel and bridge location. 


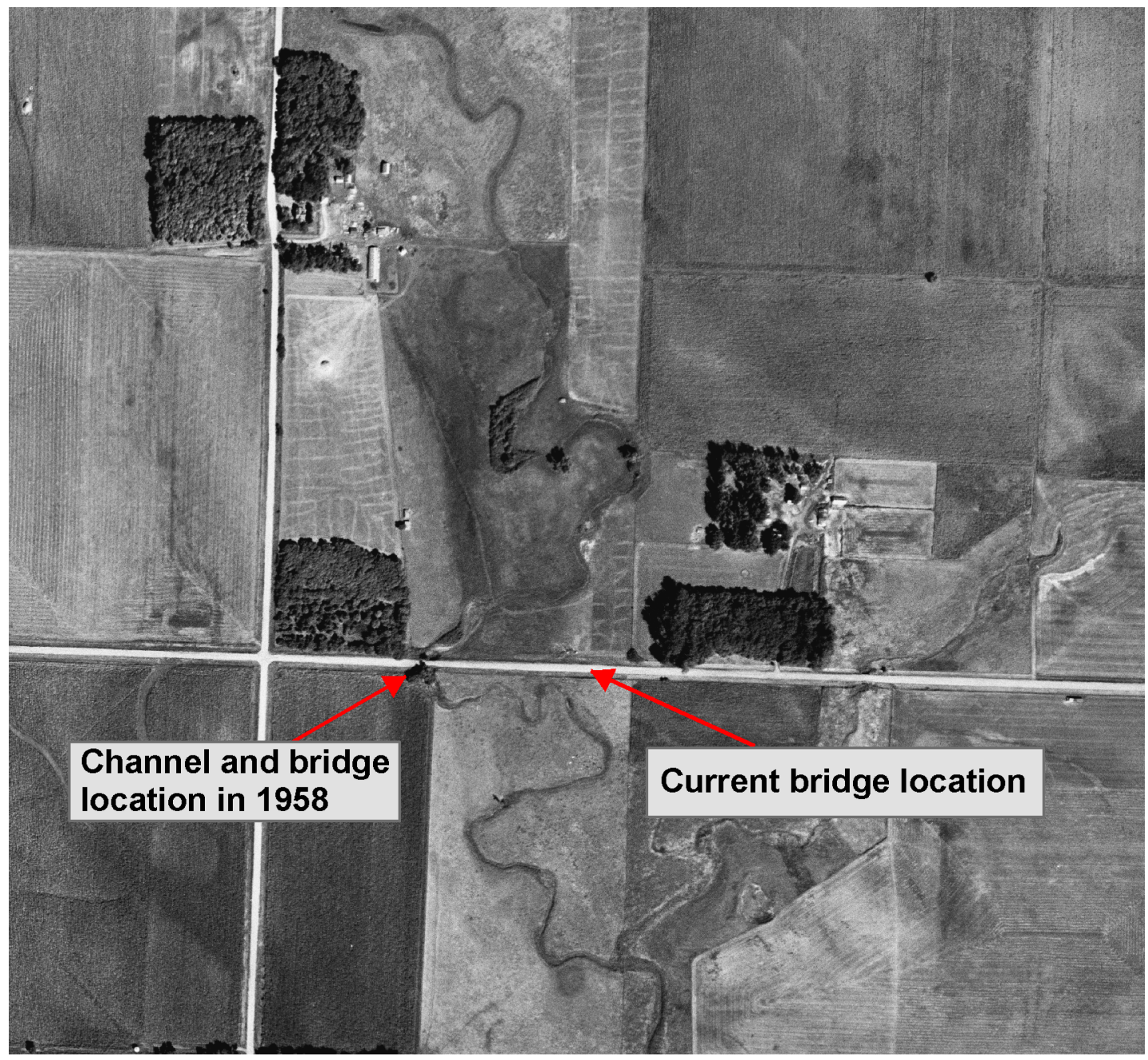

Figure 11. U.S. Geological Survey high-resolution scan of aerial photograph taken in 1958, rural Minnehaha County. 


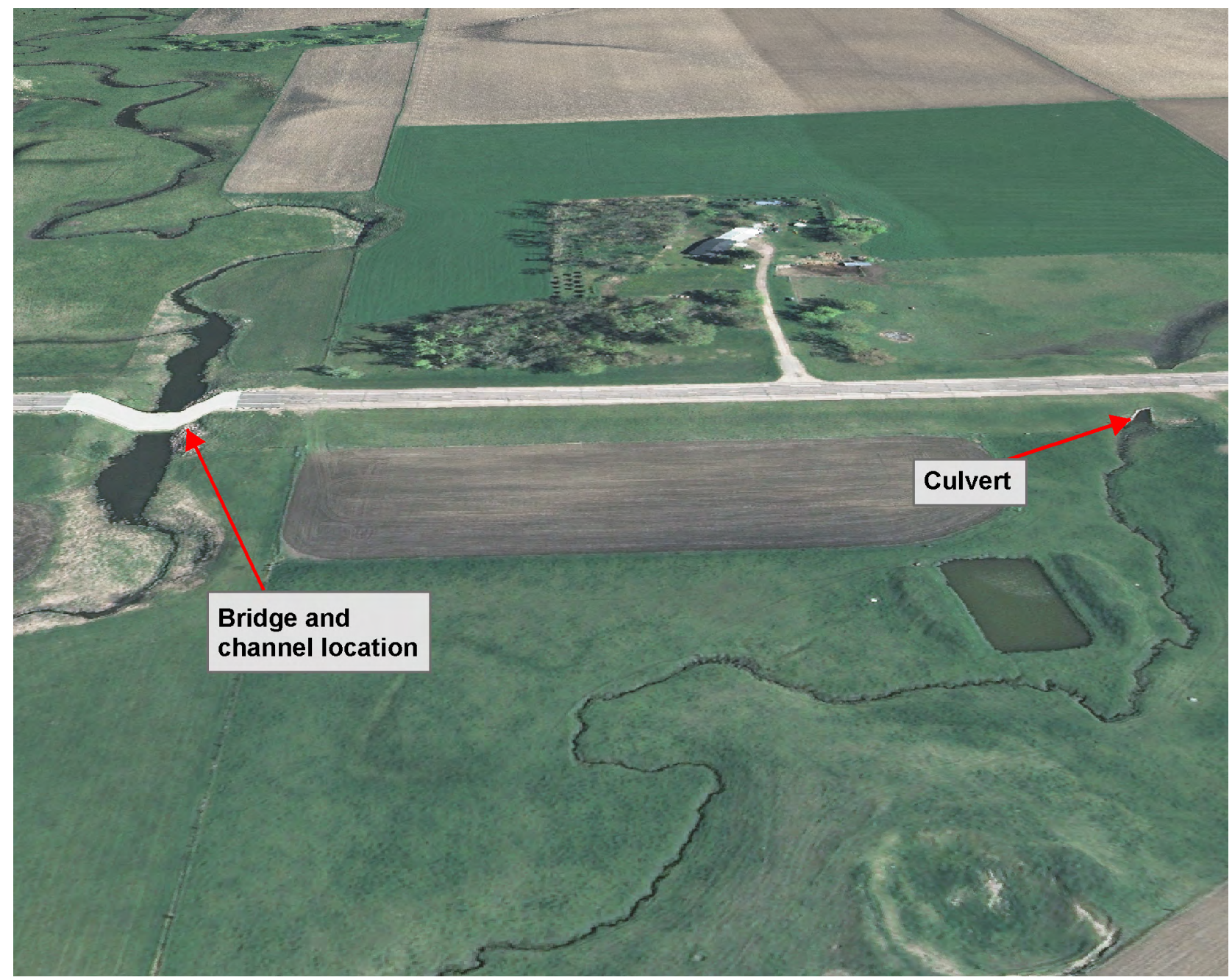

Figure 12. Aerial imagery draped over lidar-derived elevation data in rural Minnehaha County. Aerial imagery courtesy of the U.S. Geological Survey, city of Sioux Falls, Minnehaha County, and Sanborn Map Company Inc. 


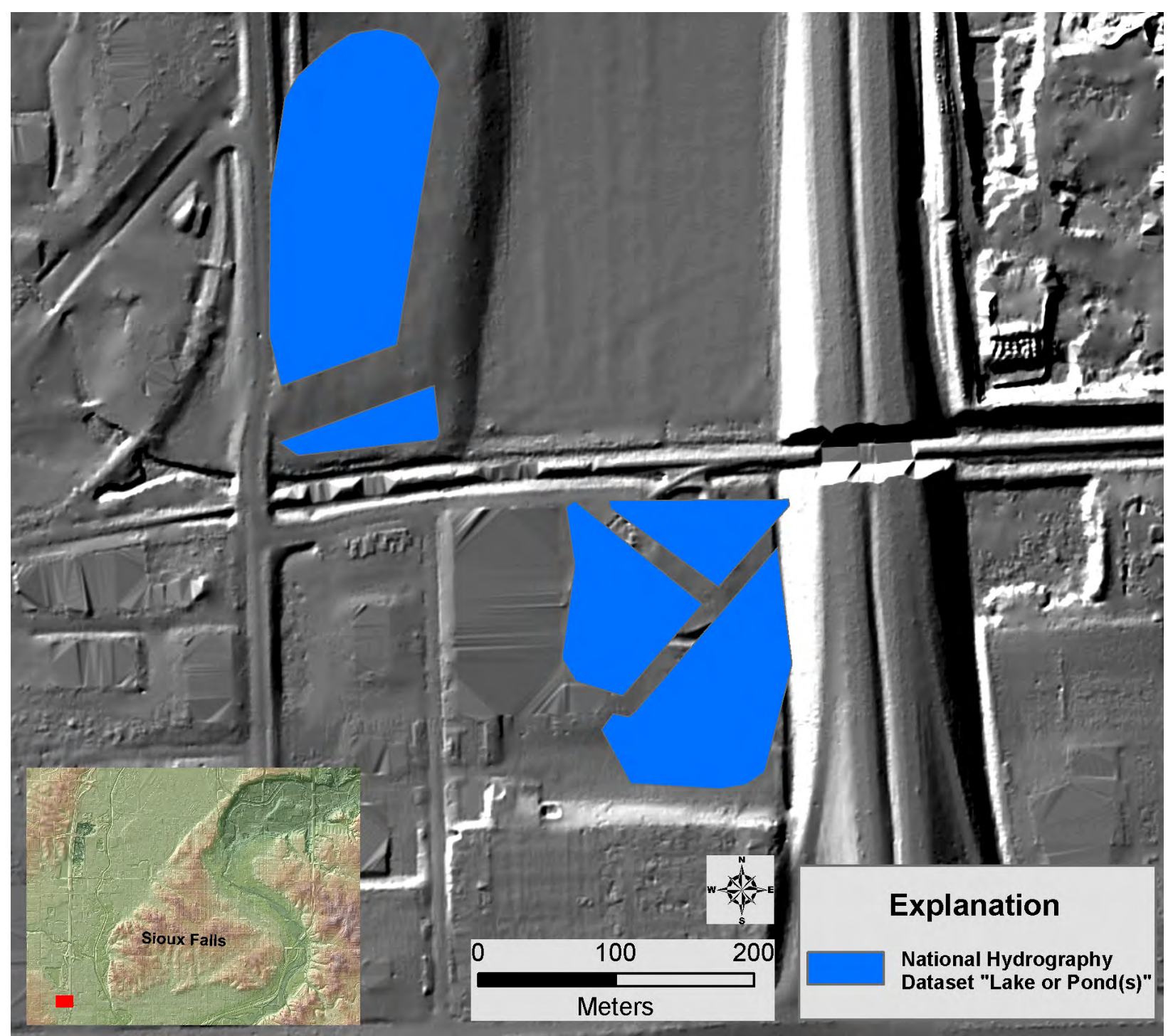

Figure 13. National Hydrography Dataset "Lake or Pond(s)" overlain on 1-meter lidar-derived elevation data located near the intersection of West 12th Street and Interstate 29, Sioux Falls, South Dakota. 


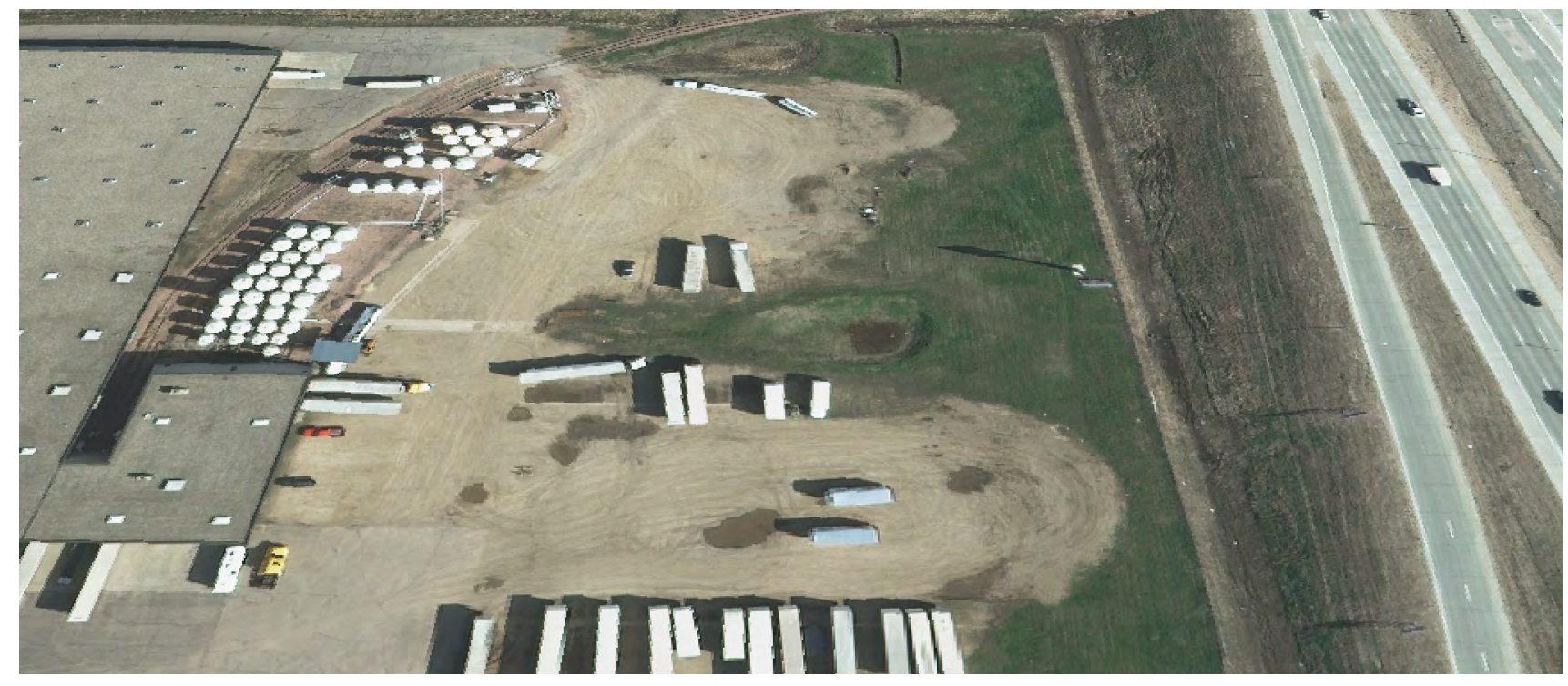

Figure 14. Aerial imagery draped over lidar-derived elevation data in a location that no longer contains National Hydrography Dataset water bodies near the intersection of West 12th Street and Interstate 29, Sioux Falls, South Dakota. Aerial imagery courtesy of the U.S. Geological Survey, city of Sioux Falls, Minnehaha County, and Sanborn Map Company Inc. 


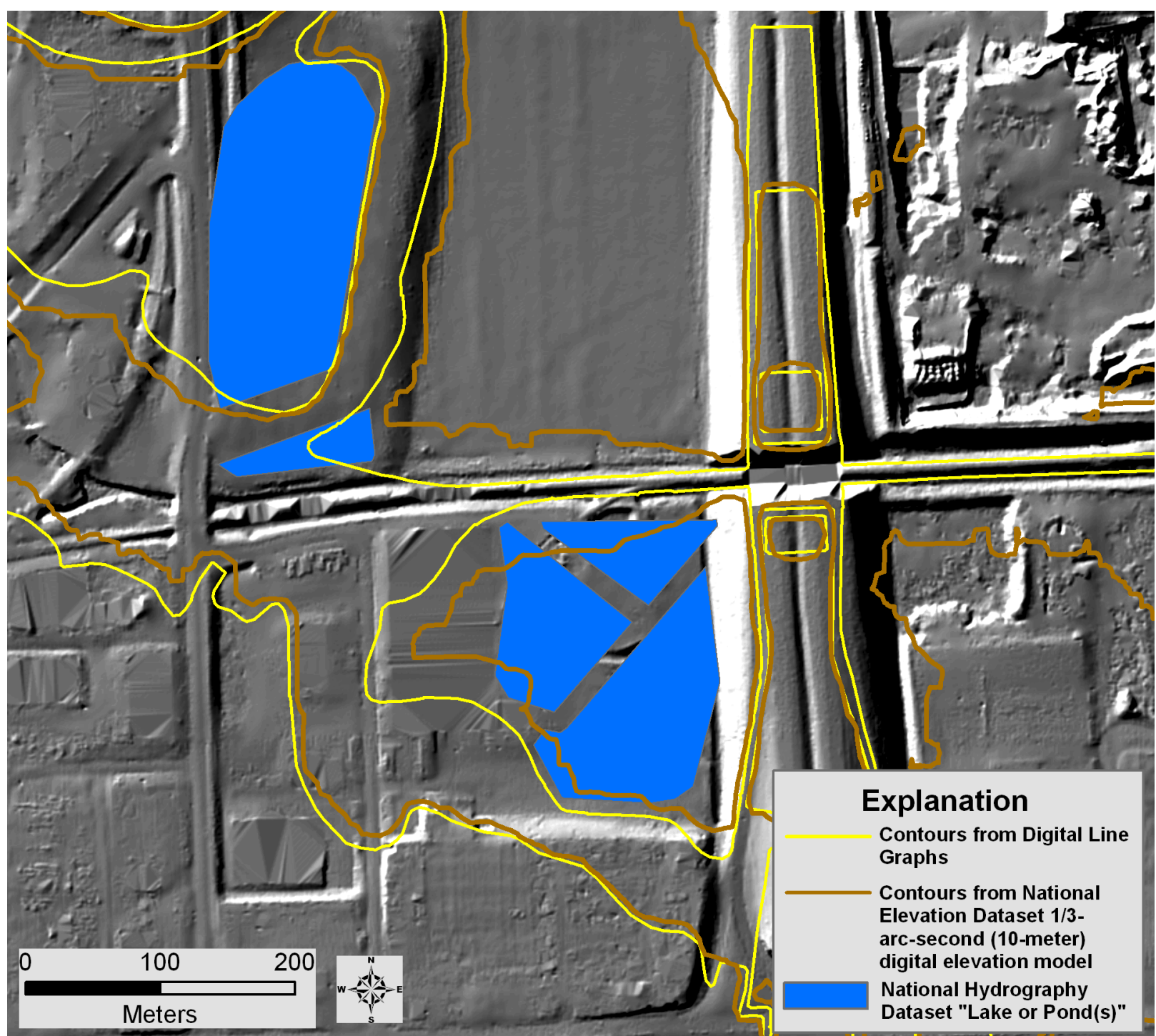

Figure 15. Contour lines from National Elevation Dataset 1/3-arc-second (10-meter) digital elevation model and from Digital Line Graphs overlain on 1-meter lidar-derived elevation data located near the intersection of West 12th Street and Interstate 29, Sioux Falls, South Dakota. 


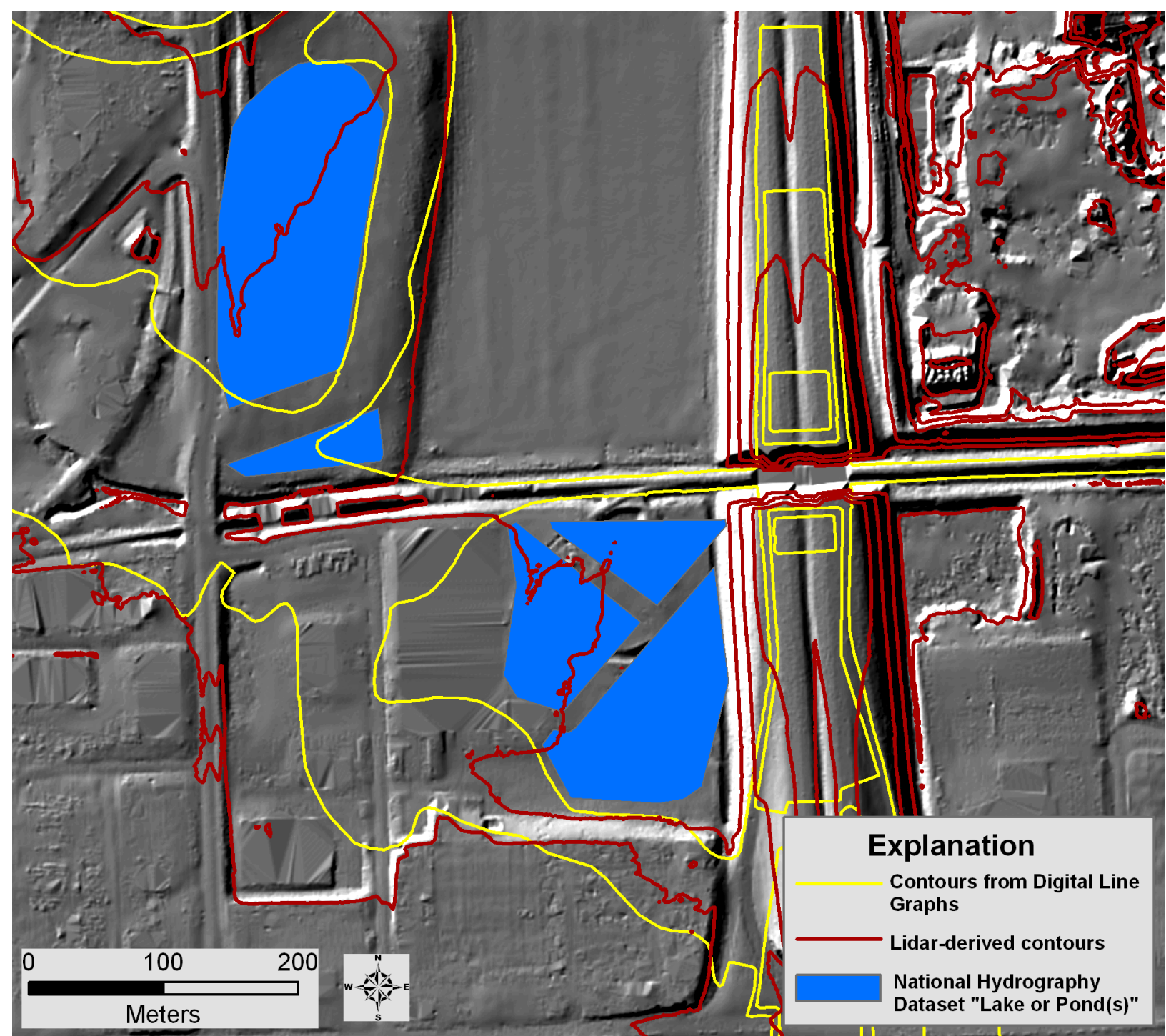

Figure 16. Contour lines from 1-meter lidar-derived digital elevation model and from Digital Line Graphs overlain on 1-meter lidar-derived elevation data located near the intersection of West 12th Street and Interstate 29, Sioux Falls, South Dakota. 
through several culverts (fig. 17). More current contour lines now represent topography in areas that were previously lakes or ponds (figs. 15 and 16). To that end, using contour lines from DLGs to hydrologically enforce elevation will produce results that mimic older inaccurate map data.

These comparisons exemplify the currency issues that arise when attempting to integrate geographic data developed at various time intervals. USGS National Map Accuracy Standards indicate horizontal accuracy needs to be within
12.19 meters (40 feet) at a 1:24,000 scale map (U.S. Geological Survey, 1999). In keeping with the USGS goal of providing the best publicly available elevation data, the Minnehaha County 1-meter lidar-derived elevation data meet the National Map Accuracy Standards and are currently the best publicly available elevation data to represent topography and applications of surface-water data. Therefore, surface flow features were developed from the Minnehaha County lidar data.

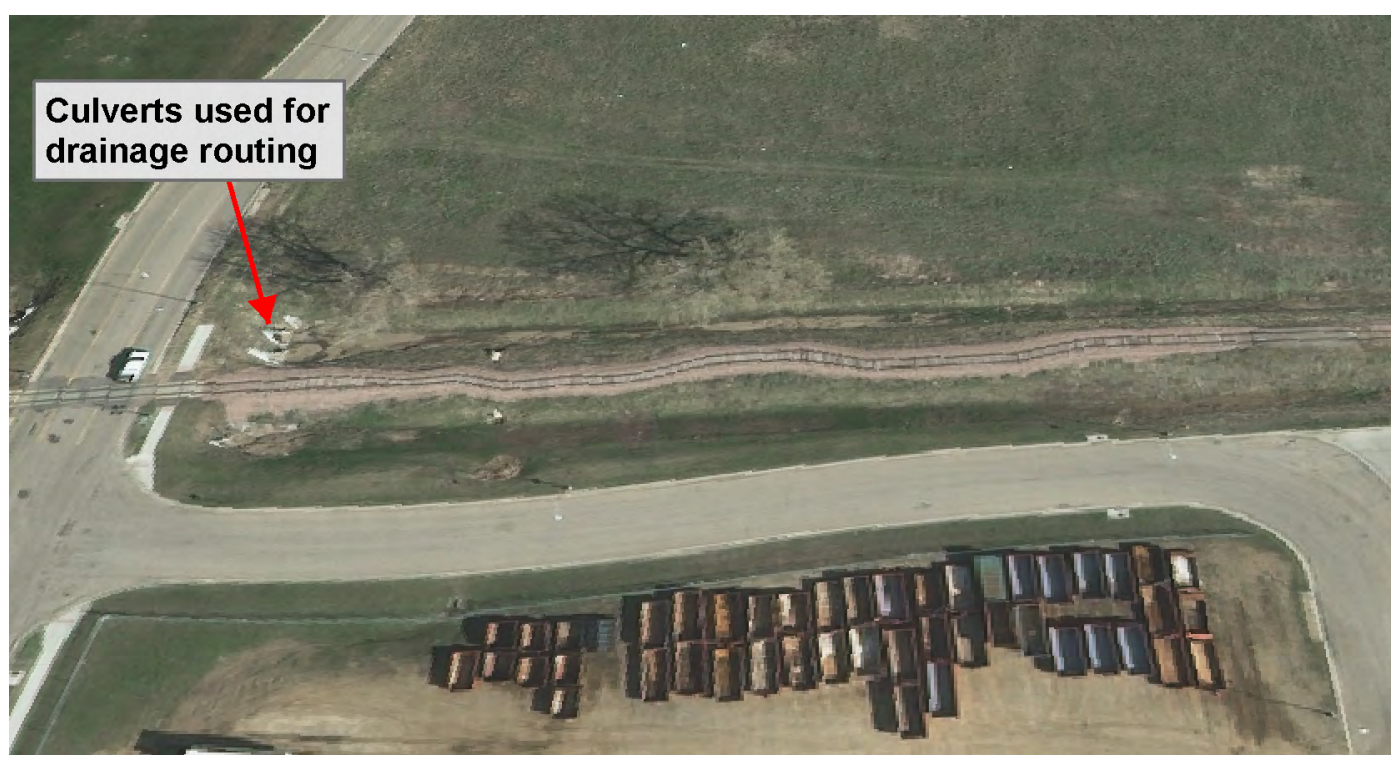

Figure 17. Aerial imagery draped over lidar-derived elevation data in a location where National Hydrography Dataset "Lake or Pond(s)" once existed near the intersection of West 12th Street and Interstate 29, Sioux Falls, South Dakota. Aerial imagery courtesy of the U.S. Geological Survey, city of Sioux Falls, Minnehaha County, and Sanborn Map Company Inc. 


\section{Surface Flow Features Derived from Lidar}

Surface flow features derived from lidar are high resolution, hydrologically integrated, and consistently generated. The elevation data were hydrologically conditioned using techniques developed by Jenson and Domingue (1988). This method is a conditioning phase that generates three datasets: the original DEM with depressions filled, a dataset indicating the flow direction that represents the steepest down slope direction for each cell, and a flow accumulation dataset in which each cell receives a value equal to the number of cells that drain to it. Sinks are identified by subtracting the original DEM from the filled depressionless DEM. The filling of depressions allows surface routing across all cells in the dataset. Because of the detailed nature of lidar data, more research is needed to develop methods to systematically remove flow obstructions, such as bridges, from lidar-derived surface flow (fig. 18). This need is described in more detail in the section of this report titled "Implications for Further Study and Additional Capabilities."

Two methods were used to conduct comparisons between surface flow features derived from a hydrologically conditioned lidar-derived DEM and ancillary hydrography datasets including EDNA and NHD: a contributing area threshold and a downstream trace (raindrop analysis) technique. The first generation of surface flow features (channels) developed from

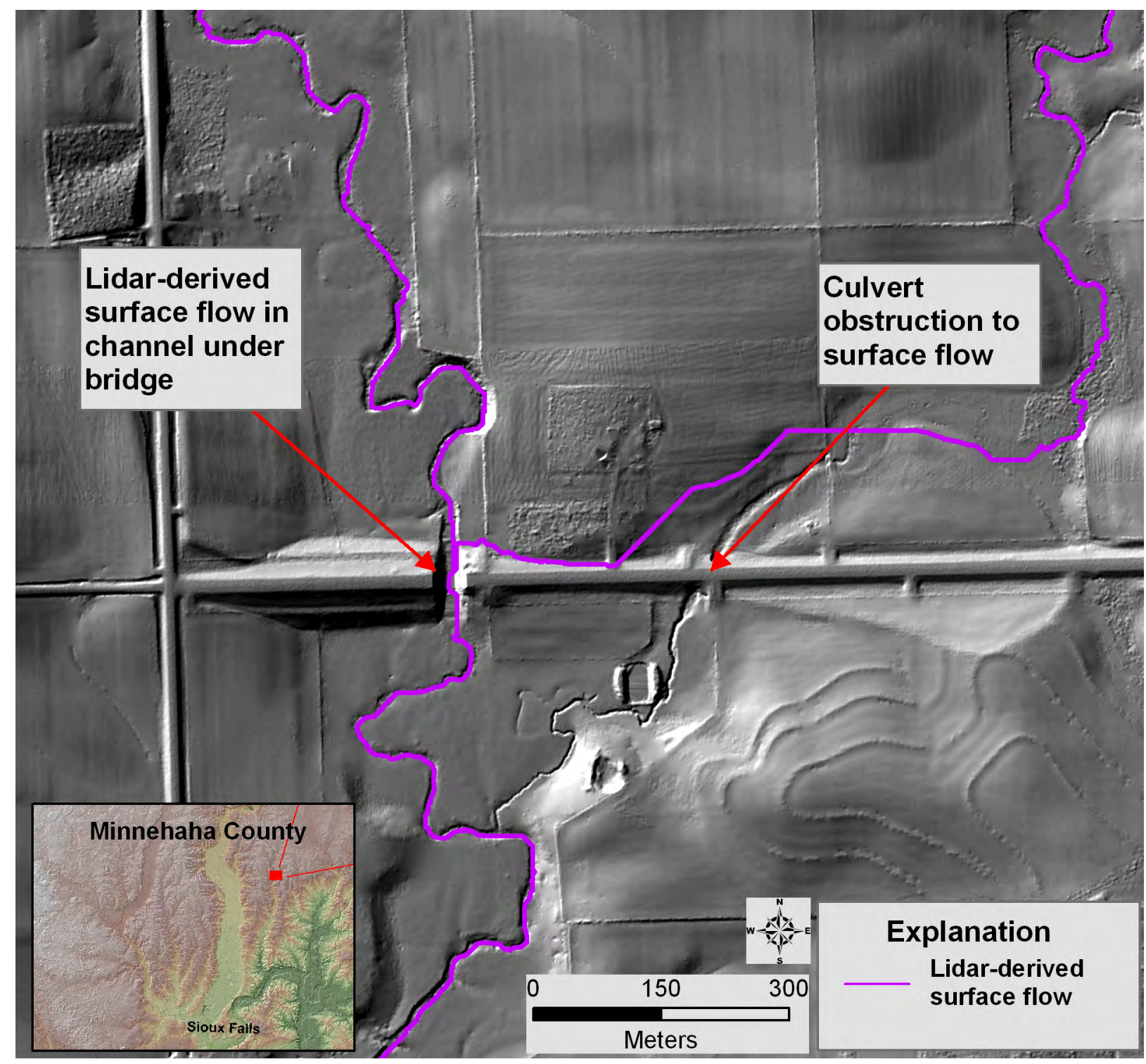

Figure 18. Lidar-derived surface flow features overlain on 1-meter lidar-derived elevation data in rural Minnehaha County. Note: In this bare earth lidar-derived elevation surface, the bridge (left side of image) was removed from the elevation data by the lidar vendor when the lidar point cloud data were processed. 
lidar was based on a contributing area threshold using the flow accumulation raster, which creates a channel network with a uniform drainage density and some small short headwater channels (fig. 19A). Although different drainage network densities may be needed for various applications, using contributing area threshold channel networks with existing cartographically derived channels can become challenging.

The second generation of surface flow features (channels) was based upon a downstream trace (raindrop) method where cartographically derived headwater reaches (NHD) were processed to extract the uppermost point on the reach. These points were used to "seed" a downstream trace or "raindrop" trace by using the filled DEM and related flow direction. Unlike the contributing area threshold, the downstream trace method uses predetermined points to define headwaters to delineate downstream channels, and the result is a drainage density that more closely mimics the cartographically derived hydrography (fig. 19B).

Comparing lidar-derived surface flow generated from a hydrologically conditioned DEM with the downstream trace (raindrop) surface flow derived from NHD headwater reaches reveals some of the issues regarding integration and mapping of flow channels on the landscape. Figure 19 contains a headwater location in an agricultural field. The flow channels derived by using a contributing area threshold (fig. 19A) contain a more dense drainage network than the downstream trace channel (fig. 19B). Additional channels depicted in the lidar elevation data were not captured in the cartographically controlled downstream trace. When rendering a map at a given scale, it is necessary to control the number of features (detail) in a way that is appropriate for that scale. In this case, the cartographically based dataset was developed at a set scale, and the inclusion and exclusion of some features are somewhat subjective.

Downstream trace (raindrop) surface flow and the NHD flowlines were compared for the same agricultural field location (fig. 20). There is some deviation between the DEM-derived downstream trace channel and the cartographic channel. The largest disagreement between the two channels is about 36.5 meters (120 feet).

\section{Implications for Further Study and Additional Capabilities}

During the generation of lidar-derived surface flow features, several issues became evident regarding the integration and mapping of flow channels on the landscape. The following are some examples of methods, technologies, and models that are being refined and tested to enhance the use of lidar in deriving surface flow features.

Because of lidar's fine-scale ability to represent the topographic surface of the earth, a vast amount of detail is captured in the bare earth lidar data. Using a depressionless DEM to create overland surface flow provides more accurate surface channels when obstructions, such as bridges, are removed. However, if such obstructions are not removed, the filling of sinks to create overland flow tends to either unnecessarily spill the flow over the obstruction in the wrong location or drain the flow in the opposite direction (fig. 18). Ongoing research is testing a selective draining method that will be implemented in future development of surface flow features from lidar.

In the process of identifying sinks in the hydrologic conditioning phase, a difference grid was created by subtracting the values of the original lidar DEM from the filled depressionless DEM. The deepest and shallowest cells could be identified in the sink(s) by using the highest and lowest values of the difference grid (fig. 21). In many cases, the deepest point in the sink could be used to drain through or under an obstruction, such as a bridge. Knowing the shallowest point is valuable in determining where water would overflow from the sink in the event of a flood when the drainage channels (through a culvert or bridge) could not accommodate the floodwaters. Additional research is being conducted to use these points to create overland flow as opposed to removing elevation data from the bare earth lidar, such as the location of bridges or culverts, where valuable transportation network information is lost by doing so.

One of the many benefits of deriving surface flow features from lidar is the ability to delineate watersheds. Elevation-derived watersheds provide a framework to quantify hydrologic footprint characteristics so that researchers can evaluate the health of the Nation's watersheds (Poppenga and Worstell, 2008). Both the contributing area threshold and downstream trace methods were digitally created using the flow direction matrix (steepest slope) from the lidar-source DEM. The flow direction matrix provides the necessary data to support watershed delineation tools, which is a capability that is not an option when using traditional cartographic datasets.

Future lidar applications will include the development of a water dataset (mask) derived from bare earth lidar data and spectral imagery. During the processing of the Minnehaha County lidar, ground points were classified by using TerraScan software by Terrasolid Limited of Helsinki, Finland. In the filtering process, points were classified as "default," "ground," or "water." This information is useful for research of extracting water body features.

\section{Conclusion}

The USGS is the primary source for seamless elevation models at the global, national, and local scales (Gesch, 2007). By implementing remotely sensed lidar-derived DEMs into the NED, the elevation layer for "The National Map," the USGS has developed a multiresolution, evolving elevation dataset that provides the best publicly available elevation data for research, applications, and data distribution. This perpetual development method needs to be applied to hydrologic derivatives to provide valuable surface flow information for 

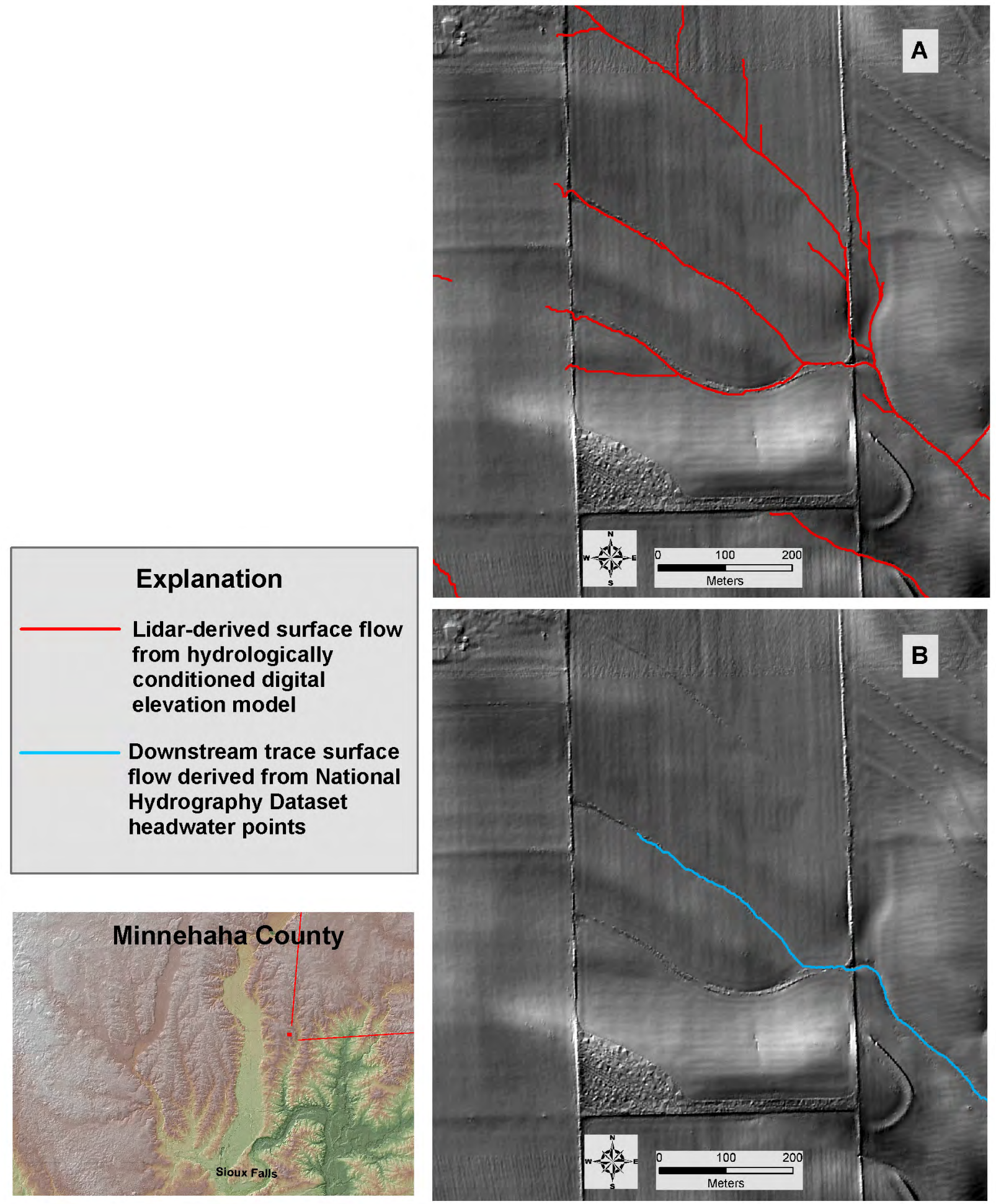

Figure 19. (A) Lidar-derived surface flow from hydrologically conditioned digital elevation model and $(B)$ downstream trace (raindrop) surface flow derived from National Hydrography Dataset headwater points. 


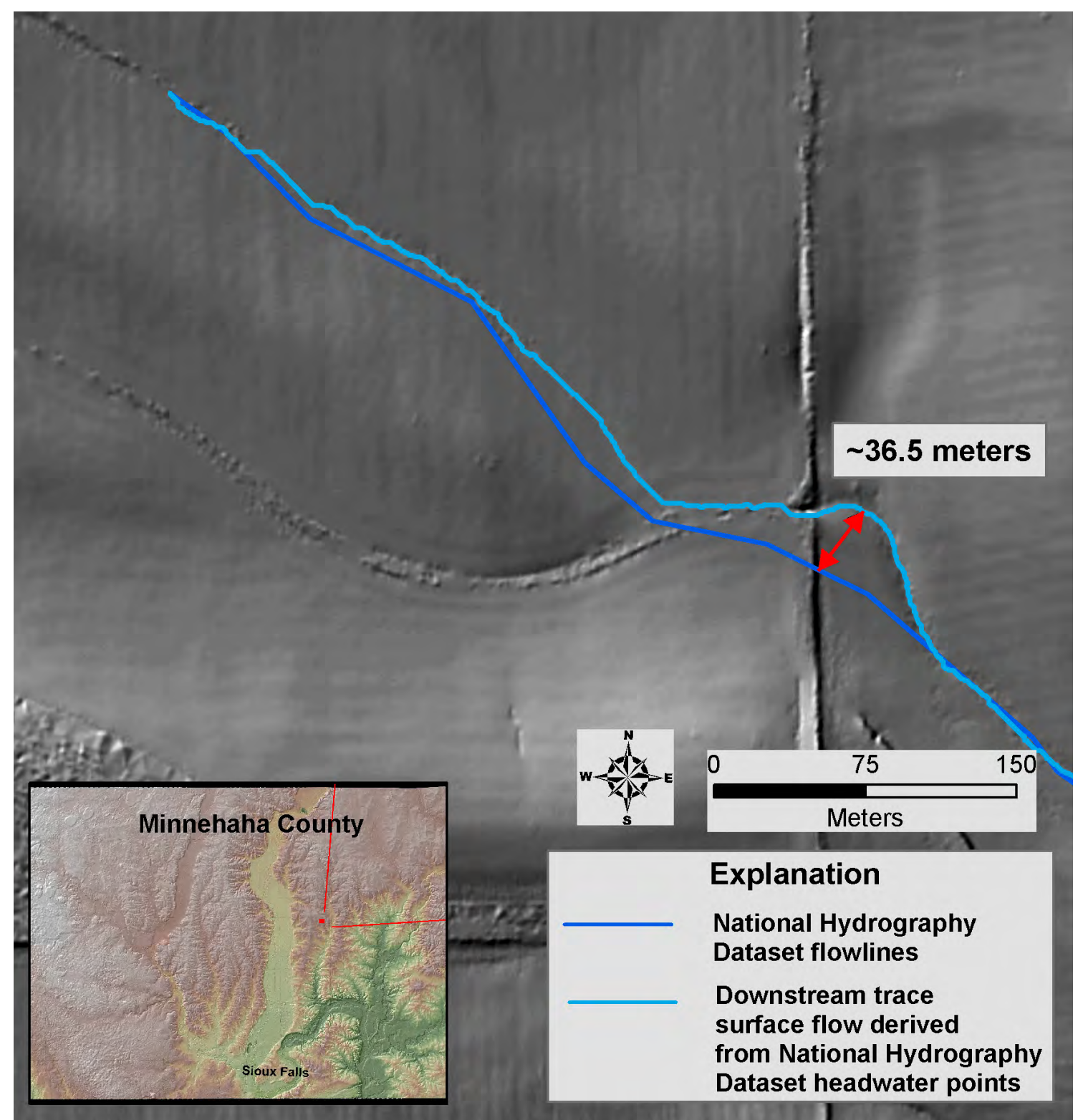

Figure 20. Surface flow from downstream trace (raindrop) method, derived from National Hydrography Dataset headwater points, and the National Hydrography Dataset flowlines.

surface-water applications. Because the USGS has identified water availability as a high priority and highlights the need for a Water Census of the United States, further research is needed to develop accurate surface flow to contribute to the determination of the status and trends in freshwater quantity and quality for human and environmental needs (U.S. Geological Survey, 2007). Because elevation is a key factor in deriving surface flow features, the best publicly available elevation data (high-resolution 1-meter lidar-derived DEMs) were used to create surface flow features in Minnehaha County, South
Dakota. Lidar-derived surface flow, historical elevation data (30- and 10-meter resolution), and ancillary hydrography datasets were compared to determine the efficacy of elevation and hydrologic integration. Surface flow features generated from lidar-derived DEMs are of high resolution and produce highly integrated hydrologic data. These remotely sensed data and their derivatives provide topographic information and data integration capabilities needed for meeting current and future human and environmental needs. 


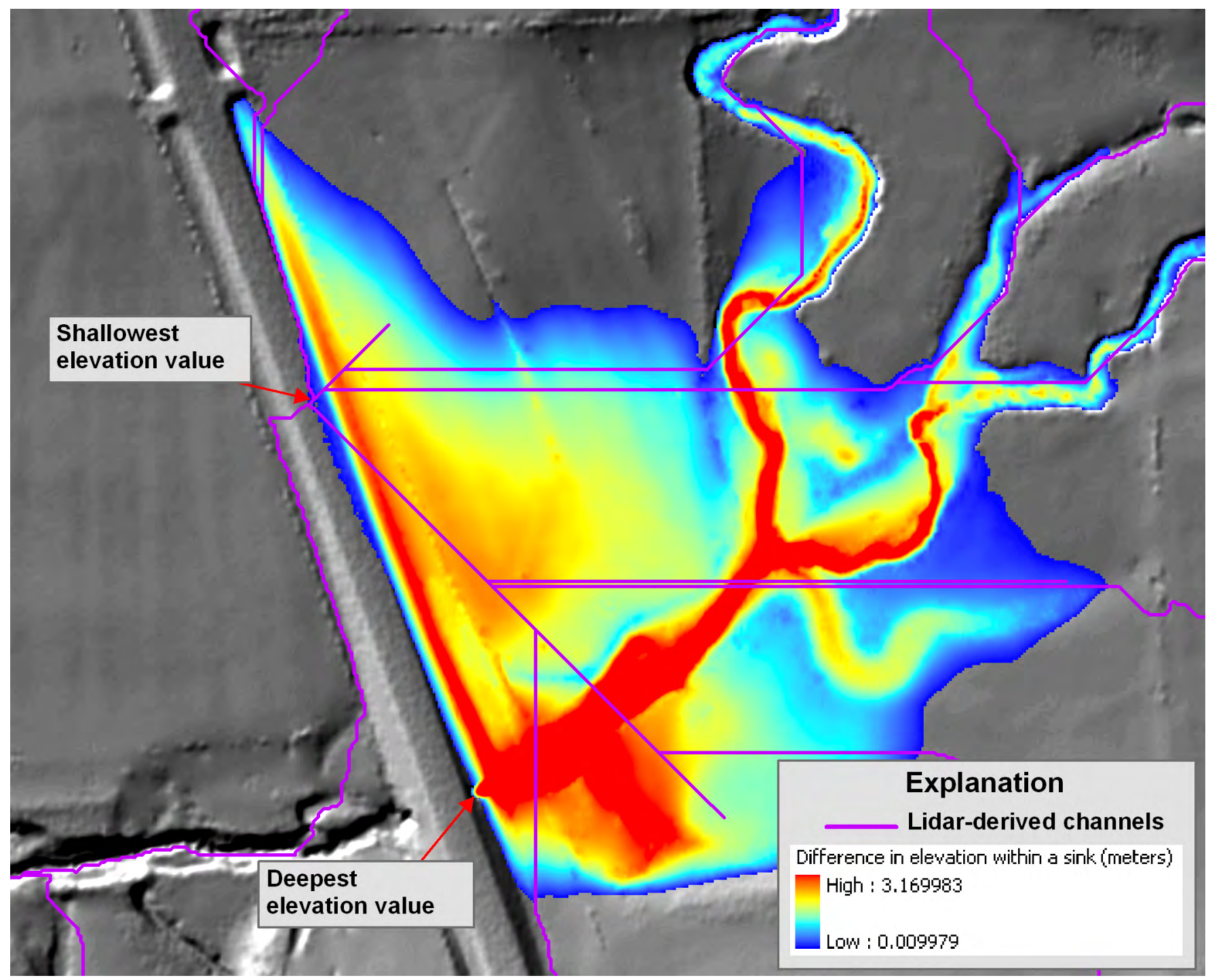

Figure 21. Difference grid resulting from subtracting values of the original lidar-derived digital elevation model (DEM) from the filled depressionless DEM. 


\section{References Cited}

Franken, S.K., Tyler, D.J., and Verdin, K.L, 2001, Development of a National seamless database of topography and hydrologic derivatives, Proceedings of the 21st ESRI User's Conference, July 9-13, 2001, San Diego. (Also available online at http://gis.esri.com/library/userconf/proc01/ professional/papers/pap730/p730.htm and on CD-ROM.)

Gesch, D.B., in press, Analysis of lidar elevation data for improved identification and delineation of lands vulnerable to sea level rise: Journal of Coastal Research.

Gesch, D.B., 2007, The National Elevation Dataset, in Maune, D., ed., Digital elevation model technologies and applications - the DEM users manual ( $2 \mathrm{~d}$ ed.): Bethesda, Md., American Society for Photogrammetry and Remote Sensing, p. 99-118.

Gesch, D., Oimoen, M., Greenlee, S., Nelson, C., Steuck, M., and Tyler, D., 2002, The National Elevation Dataset: Photogrammetric Engineering \& Remote Sensing, v. 68, no. 1, p. 5-11. (Also available online at: http://www.asprs.org/ publications/pers/2002journal/january/highlight.html)

Gesch, D.B., Verdin, K.L., and Greenlee, S.K., 1999, New land surface digital elevation model covers the earth: Eos, Transactions, American Geophysical Union, v. 80, no. 6, p. 69-70.

Hogan, E.P., and Fouberg, E.H., 2001, The geography of South Dakota (3d ed.): Sioux Falls, S. Dak., Center for Western Studies, $190 \mathrm{p}$.

Jenson, S.K., and Domingue, J.O., 1988, Extracting topographic structure from digital elevation data for geographic information system analysis: Photogrammetric Engineering and Remote Sensing, v. 54, p. 1,593-1,600.

Poppenga, S.K., and Worstell, B.B., 2008, Elevation-derived watershed basins and characteristics for major rivers of the conterminous United States, U.S. Geological Survey Scientific Investigations Report, 2008-5153, 27 p. (Also available online at http://pubs.usgs.gov/sir/2008/5153/.)

Queija, V.R., Stoker, J.M., and Kosovich, J.J., 2005, Recent U.S. Geological Survey applications of lidar: Photogrammetric Engineering \& Remote Sensing, v. 71, no. 1, p. 5-9. (Also available online at $h t t p: / / w w w . a s p r s . o r g / p u b l i c a t i o n s /$ pers/2005journal/january/highlight.pdf)
Stoker, J., Harding, D., and Parrish, J., 2008, The need for a National Lidar Dataset: Photogrammetric Engineering \& Remote Sensing, v. 74, no. 9, p. 1066-1068. (Also available online at http://www.asprs.org/publications/ pers/2008journal/september/index.html)

U.S. Census Bureau, 2008, 2005-2007 American community survey 3-year estimates, Minnehaha County, South Dakota, accessed February 6, 2009, at http://factfinder. census.gov/servlet/ACSSAFFFacts?_event=Search\&geo_ $i d=\& \_g e o C o n t e x t=\& \_s t r e e t=\& \_c o u n t y=$ Minnehaha\& cityTown $=$ Minnehaha\&_state $=04000 U S 46 \& \_z i p=\&_{-}$ lang $=e n \& \_s s e=0 n \& p c t x t=f p h \& p g s l=010$

U.S. Department of Transportation Federal Highway Administration, 2007, National Bridges Inventory, accessed December 17, 2008, at http://www.fhwa.dot.gov/bridge/nbi.htm

U.S. Geological Survey, 1999, Map Accuracy Standards: U.S. Geological Survey Fact Sheet 171-99, 2 p. (Also available online at http://egsc.usgs.gov/isb/pubs/factsheets/fs17199. html)

U.S. Geological Survey, 2007, Facing tomorrow's challenges-U.S. Geological Survey science in the decade 2007-2017: U.S. Geological Survey Circular 1309, 70 p. (Also available online at http://pubs.usgs.gov/ circ/2007/1309/.)

U.S. Geological Survey, 2008, National Hydrography Dataset: U.S. Geological Survey dataset available at http://nhd.usgs. gov

Verdin, K.L., and Jenson, S.K., 1996, Development of continental scale digital elevation models and extraction of hydrographic features, in Proceedings, Third International Conference/Workshop on Integrating GIS and Environmental Modeling: Santa Fe, N. Mex., January 21-26, 1996, National Center for Geographic Information and Analysis, Santa Barbara, Calif. (Also available online at $h t t p: / / w w w$. ncgia.ucsb.edu/conf/SANTA_FE_CD-ROM/sf_papers/ verdin_kristine/santafe2.html) 
Publishing support provided by:

Helena Publishing Service Center

For more information concerning this publication, contact:

U.S. Geological Survey Earth Resources Observation and Science (EROS) Center

Sioux Falls, South Dakota

(605) 594-6151

Or visit the EROS Center Web site at:

World Wide Web: http://eros.usgs.gov/ 
